\title{
دراسة تأثير أسلوب العناية على المفروشات المطرزة ( الفوط ) بأسلوب التطريز بشرائط الساتان
}

إعلاد

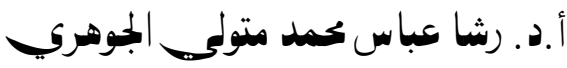

$$
\begin{aligned}
& \text { أستاذ الملابس والنسيج بقسم الاقتصاد المنزلي } \\
& \text { كلية التربية النوعية - جامعه المنصورة }
\end{aligned}
$$

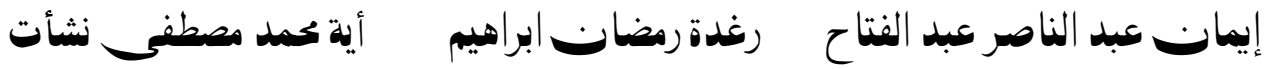

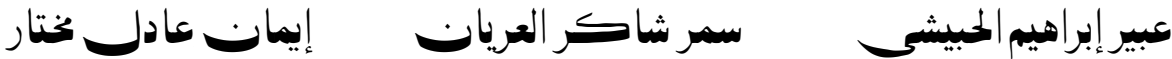

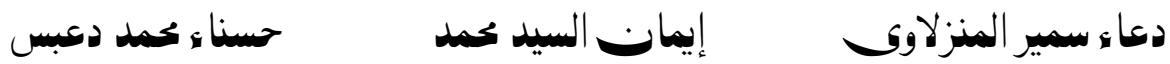

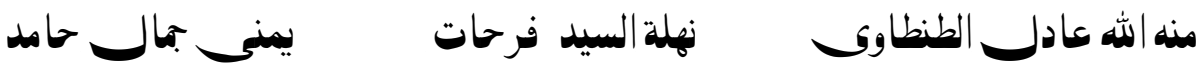

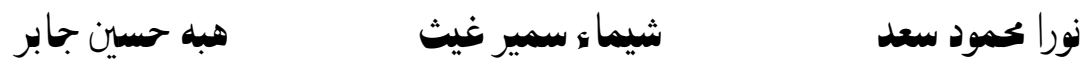

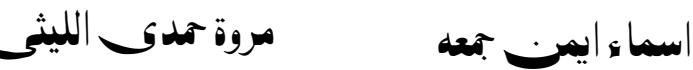

مجلة بحوث التربية النوعية ـ جامعة المنصورة

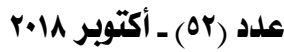


مجلة بحوث التربية النوعية - علد or - أكتوبر r.l1

\section{دراسة تأثير أسلوب العناية على المفروشات المطرزة ( الفوط ) بأسلوب التطريز بشرائط الساتان}

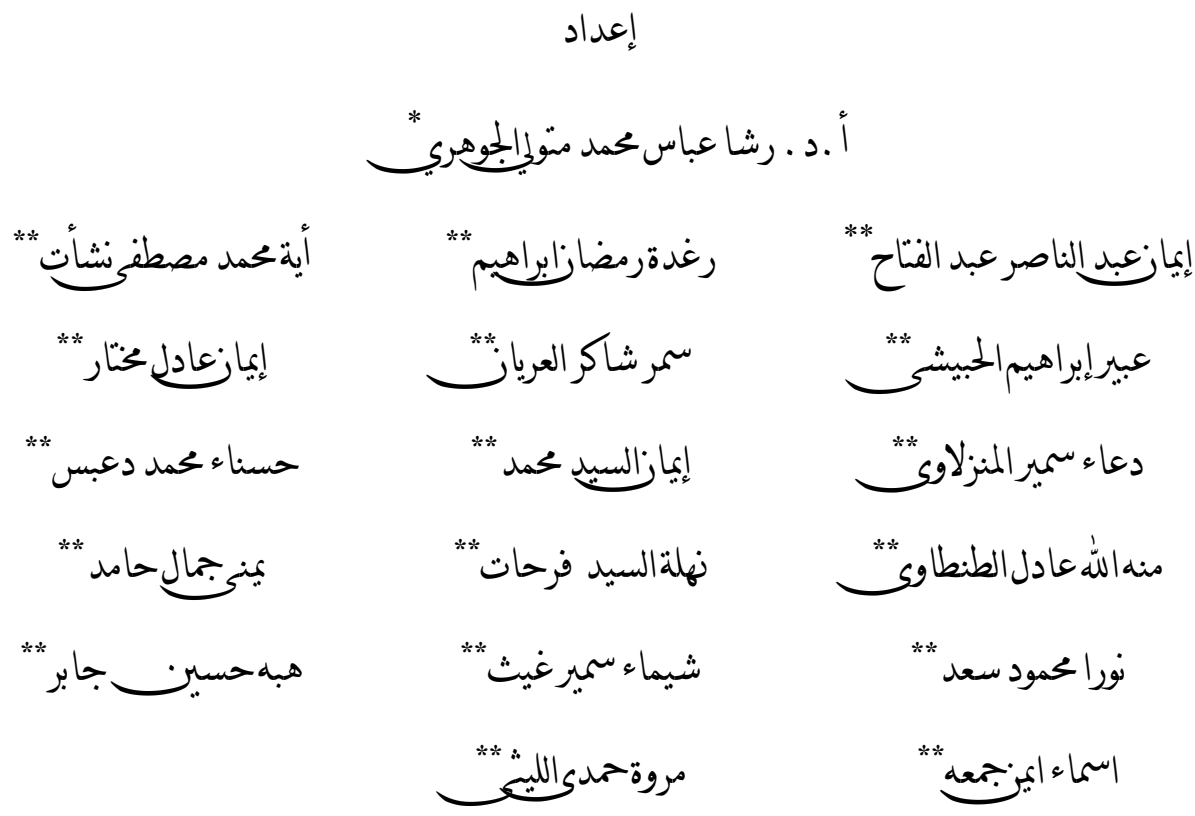

unill

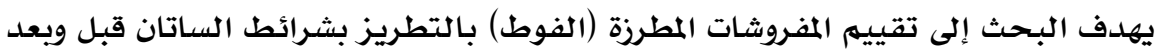

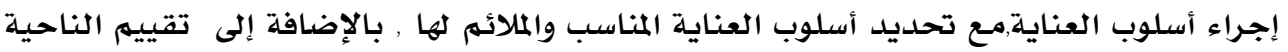

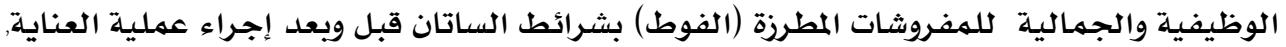

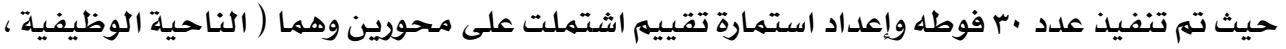

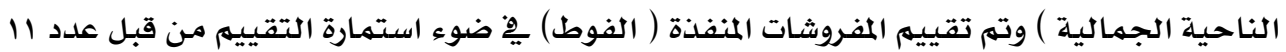

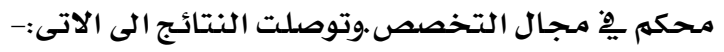

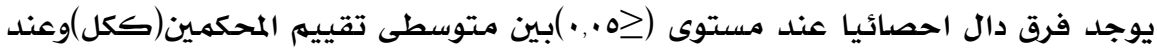

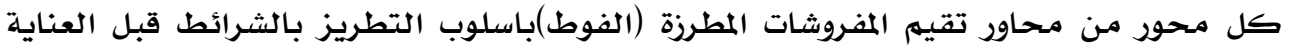

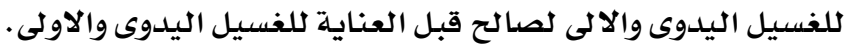


لايوجد فرق دال احصائيا عند مستوى (\ه •. • )بين متوسطى تقيم المحكمين (ككل) وعند

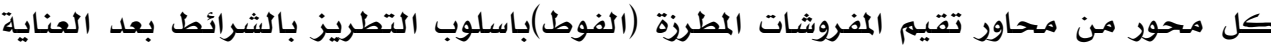

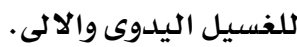

الاقدمهة والإشكلة البحثية :-

المفروشات أحد النوعيات الهامة من الأقمشة التى تقوم صناعة المنسوجات بإنتاجها

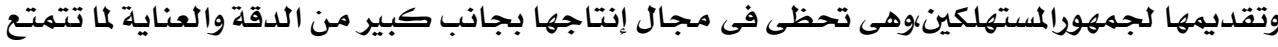

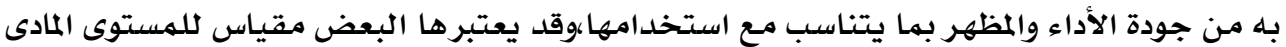

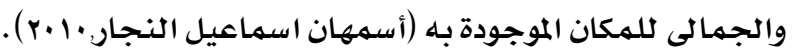

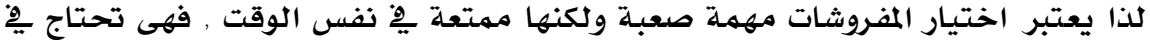

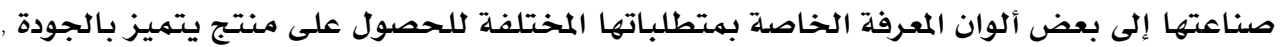

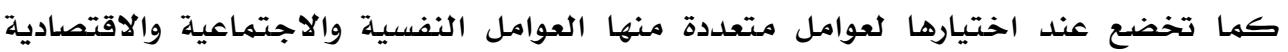

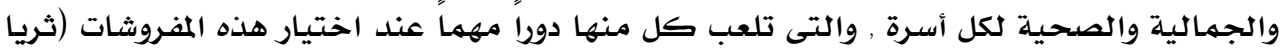

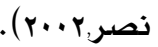

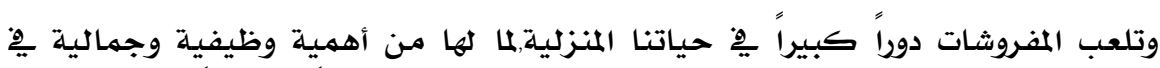

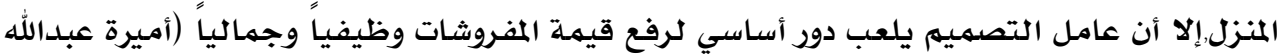
نورالدين.•r. (r) ).

ومما لاشك فيه أن المفروشات تشكل اهتماماً بالغاً بالنسبـة لكل بيت ولا بـ من من تناسق ألوان

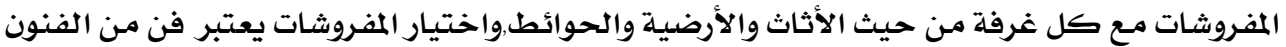

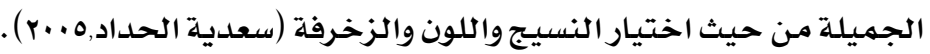

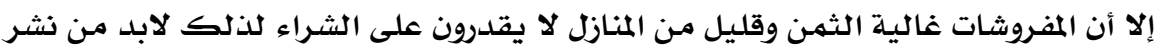

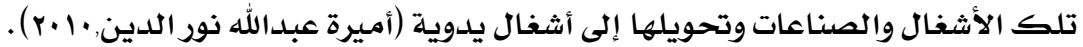
وبما أن فن زخرفة المفروشات فن عريق وحديث ولا يمكن حصر تصميماته ومبتكراته يو

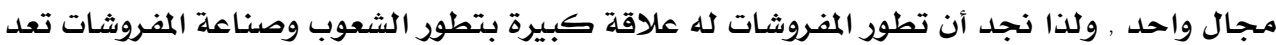
من الصناعات الأساسية ِِِ كل الحضارات وهى دليل على التقدم الحضارى والتكنولوجى لكل البلدان(سامية الطوبشي, 1999).

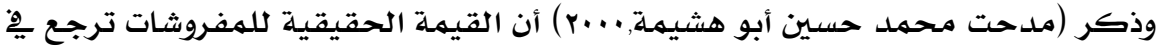

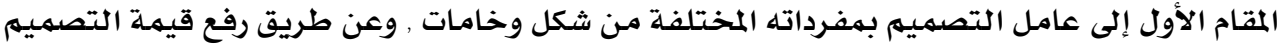

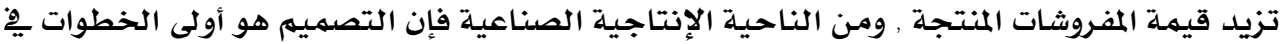

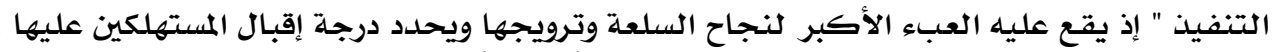

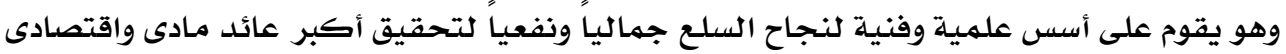

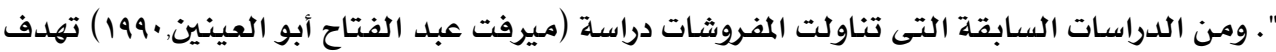


الدراسة إلى التحليل الدقيق لأهم العناصر الزخرفية الفرعونية وأساليب تكوين هذه الزخارف

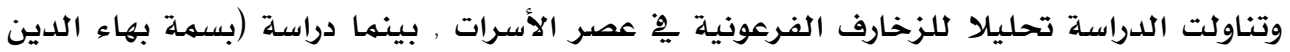

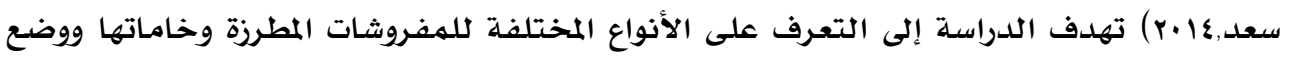

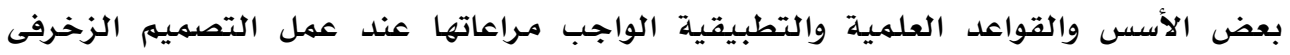

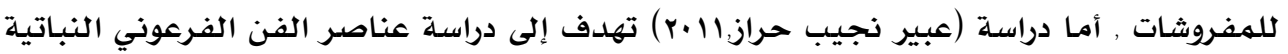

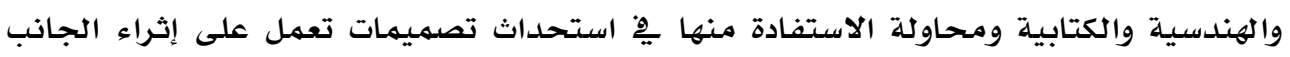

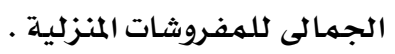

ومن "أساليب زخرفة المفروشات التطريز حيث يعتبرالتطريز واحداً من أقدم الفنون

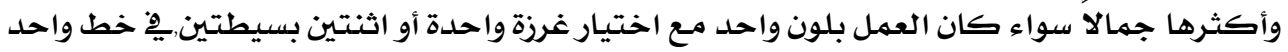

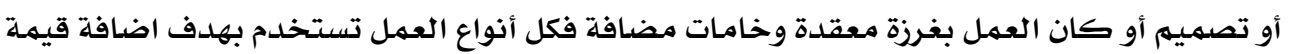

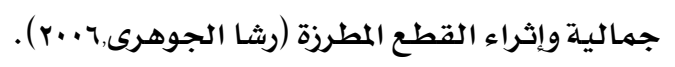

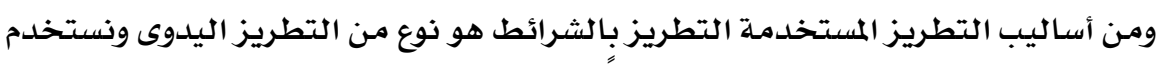

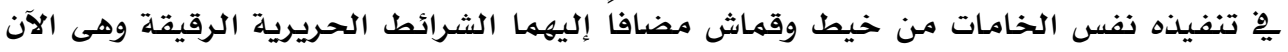

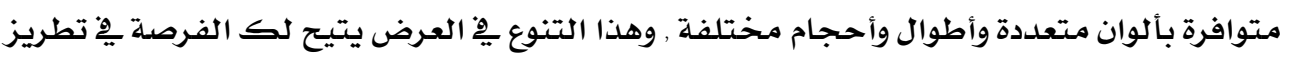

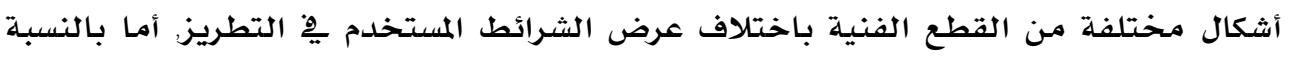

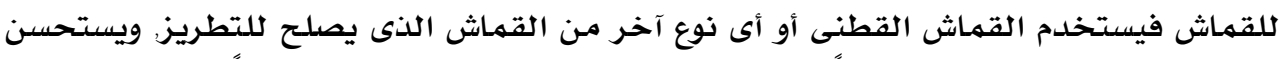

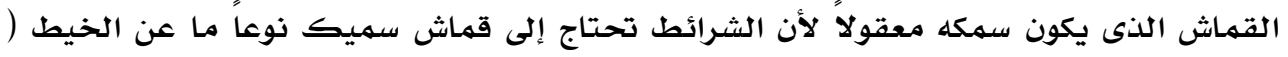

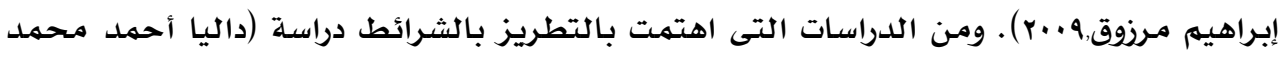

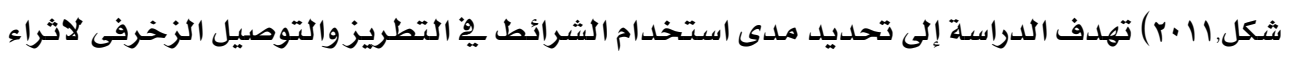

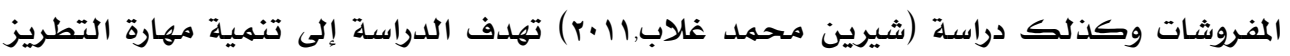

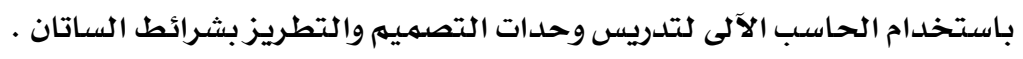
وحيث أن المفروشات المطرزة تحتاج إلى أسلوب عناية خاص بها للحفاظ على المفروشات,

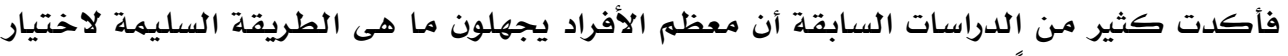

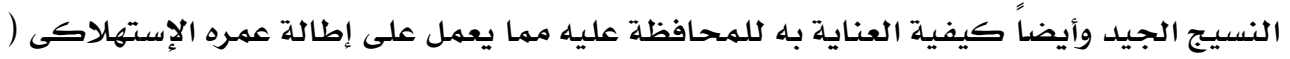

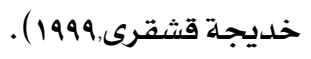

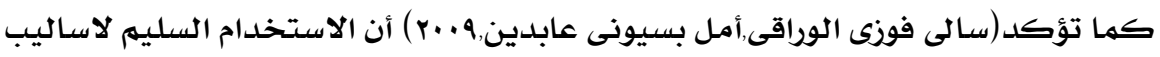

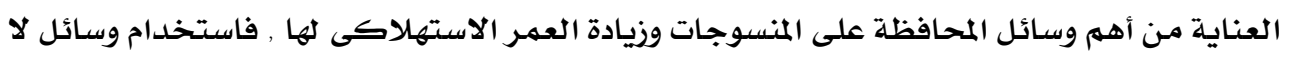

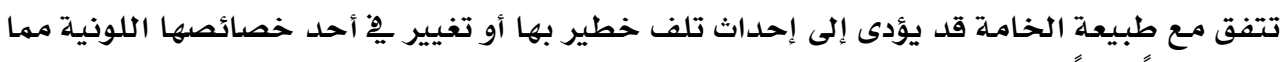

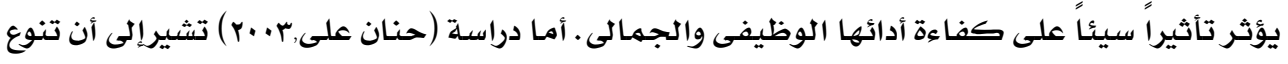

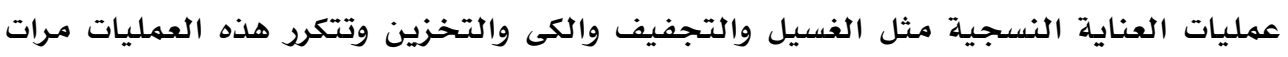

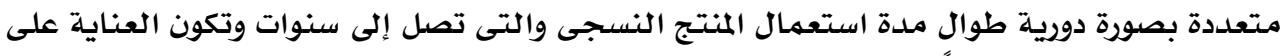

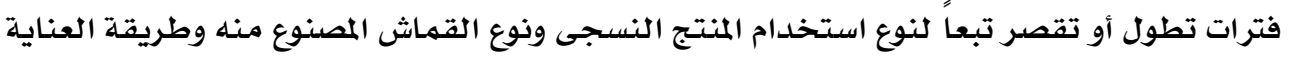


الخاصة بـه . ومن الدراسات أيضا التى اهتمت بالعناية بالمفروشات المطرزة دراسة (وفاء فؤاد

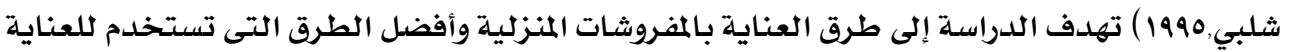

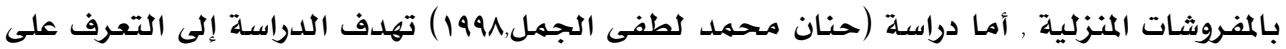

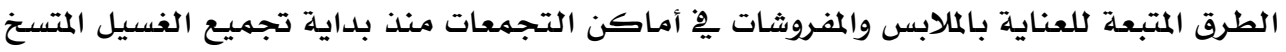

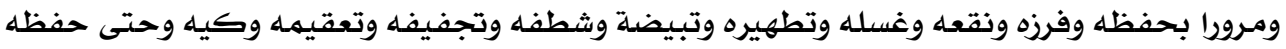

ومن خلال العرض السابق تتضـح أهمية المفروشات ودورها الفعال ِِّ حياتنا اليومية ودور

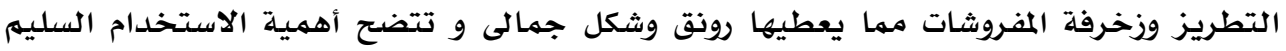

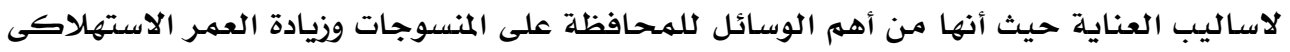
لها

\section{ومن هنا تتضح مشكلة البحث ِِ التساؤل الرئيس التالى :}

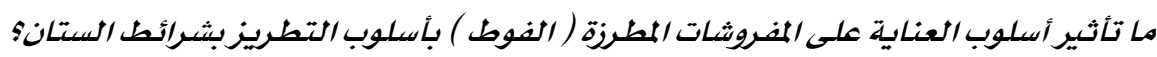

$$
\text { ويتفرع من هذا التساؤل التساؤلات التالية : }
$$

ا. ـكيف يمكن الاستفادة من التطريز بالشرائط يِّ إثراء الناحية الوظيفية للمفروشات المطرزة ؟

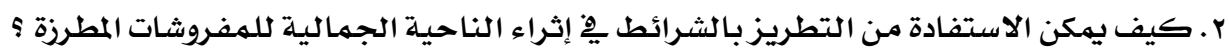

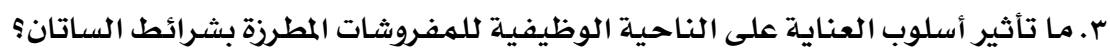

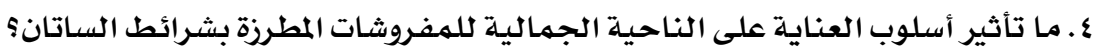

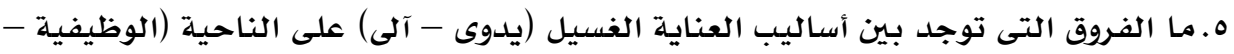

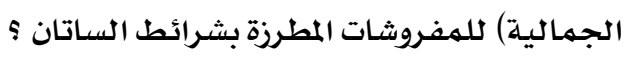

| الأهد|ف-: -

استهدف هذا البحث دراسة تأثير العناية على المفروثات المطرزة (الفوط) بأسلوب التطريز بالشرائط وذلك من خلال الأهداف الفرعية التالية:-

ا ـ تقييم المفروشات المطرزة (الفوط) بالتطريز بشرائط الساتان قبل وبعد إجراء أسلوب العناية.

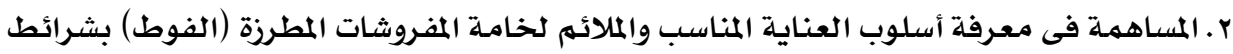
السـاتان.

r. تقييم الناحية الوظيفية للمفروشات المطرزة (الفوط) بشرائط الساتان قبل وبعد إجراء عملية العناية. ع. تقييم الناحية الجمالية للمفروشات المطرزة (الفوط) بشرائط الساتان قبل وبعد إجراء عملية العناية. 


\section{الأهميهية:- \\ ترجع أهمية البحث إلى:-}

ا. التعرف على أسلوب العناية الملائم للاستعمال مـع المفروشات المطرزة (الفوط) بشرائط الساتان.

r · يسهم هذا البحث فى إضافة أسلوب زخرفة المفروشات (الفوط) المطرزة بشرائط الساتان.

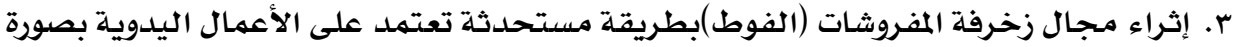
غير مكلفة. ع. إلقاء الضوء على أهمية التطريز بالشرائط ومجالات استخدامـه.

هنهم البمث: المنهج الوصفى و المنهج التجريبى. هدود البمث :-

$$
\text { • حدود نوعية :- القطع المنفذة : مفروشات (الفوط ). }
$$

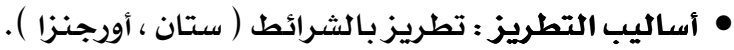

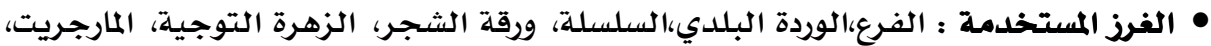

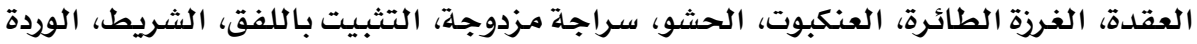

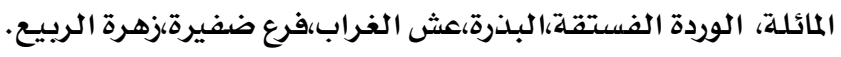
- الخامة المستخدمة : خامـة قطنية ـ. 1.

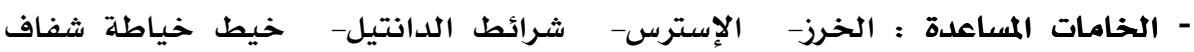

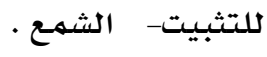

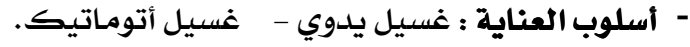

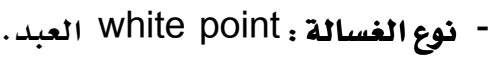

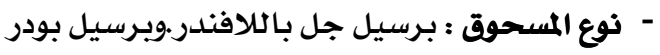

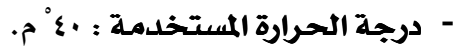

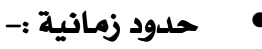

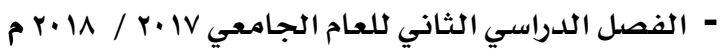




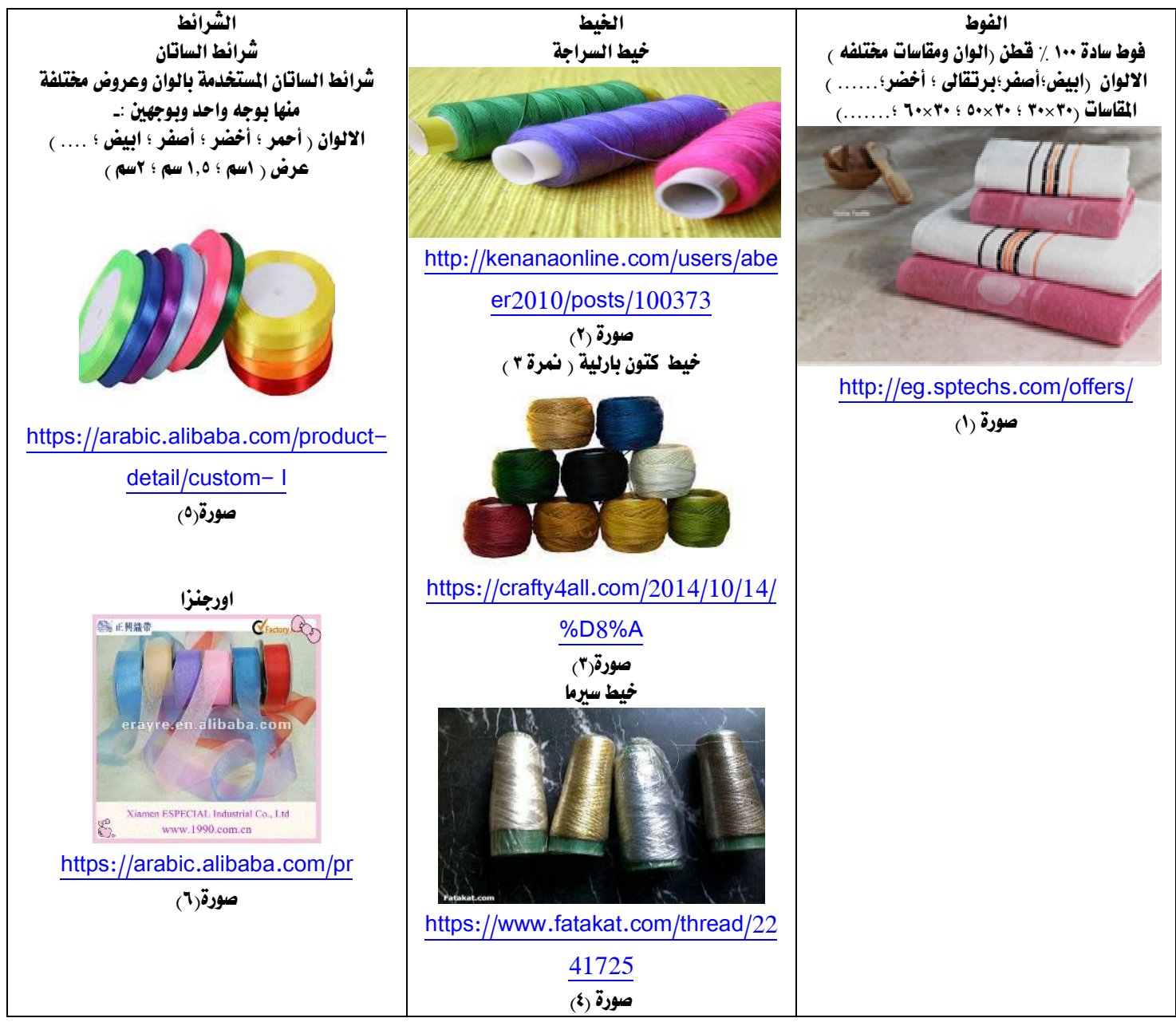




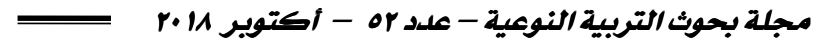

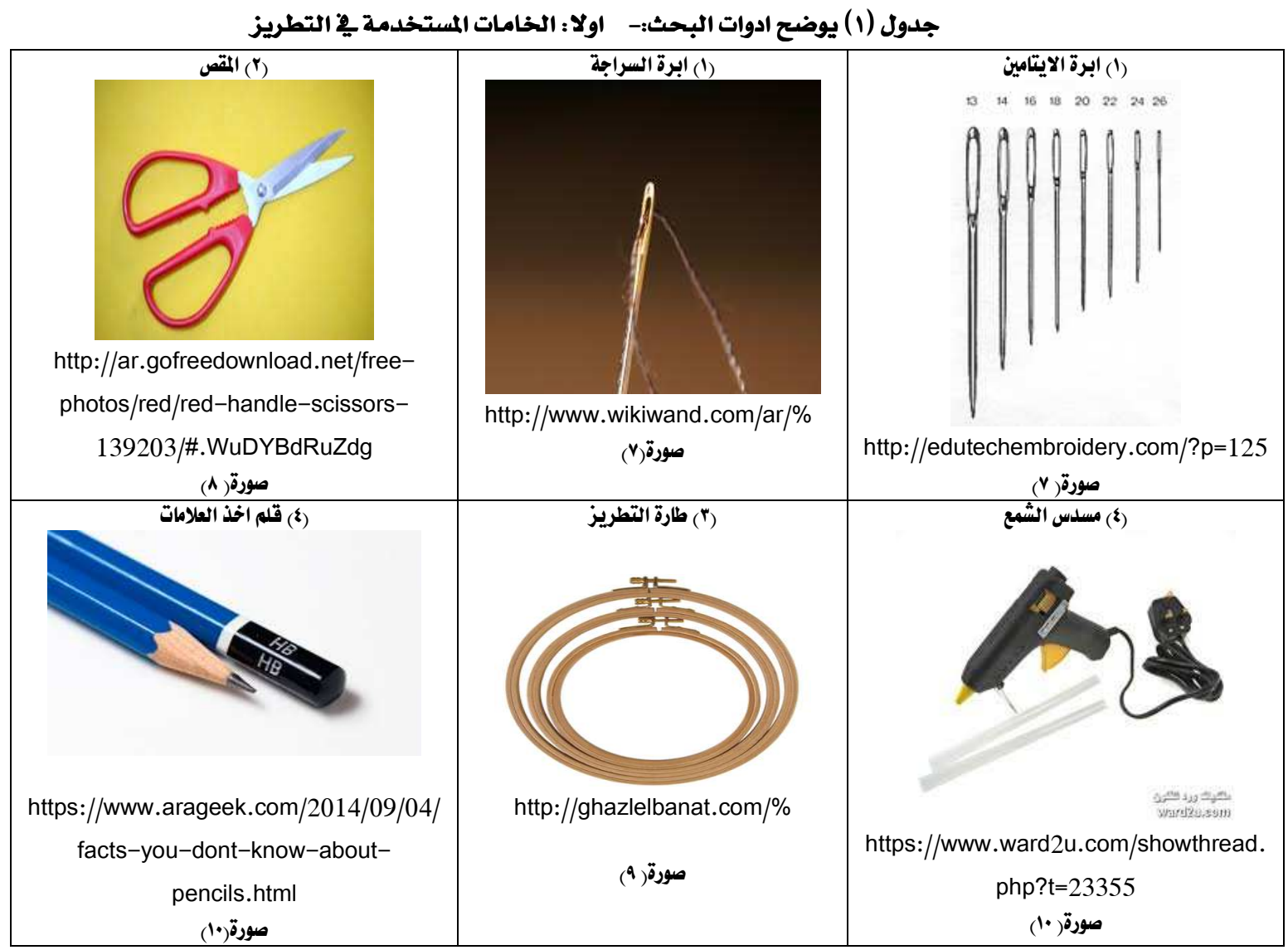

تابع جدول (1) يوضح ادوات البحث:- اولا: الخامات المستخدمة فِ التطريز

\begin{tabular}{|c|c|c|c|}
\hline \multicolumn{4}{|c|}{ ثُآًاً : الخامات المساعلة } \\
\hline الاستزس & خرز لولى & الشمع & شرائط الداتتيل \\
\hline http://forums.betel3z.c & https://vb.3dlat.com/sh & https://www.ward2u.com/s & http://www.vb.eqla3. \\
\hline om/t24229-2 & owthread.php?t=28452 & howthread.php?t=23355 & com/showthread.php \\
\hline صورة) & صورة(rا) & صورة (II) & $\frac{? p=47285397}{\text { (II) صورة }}$ \\
\hline
\end{tabular}




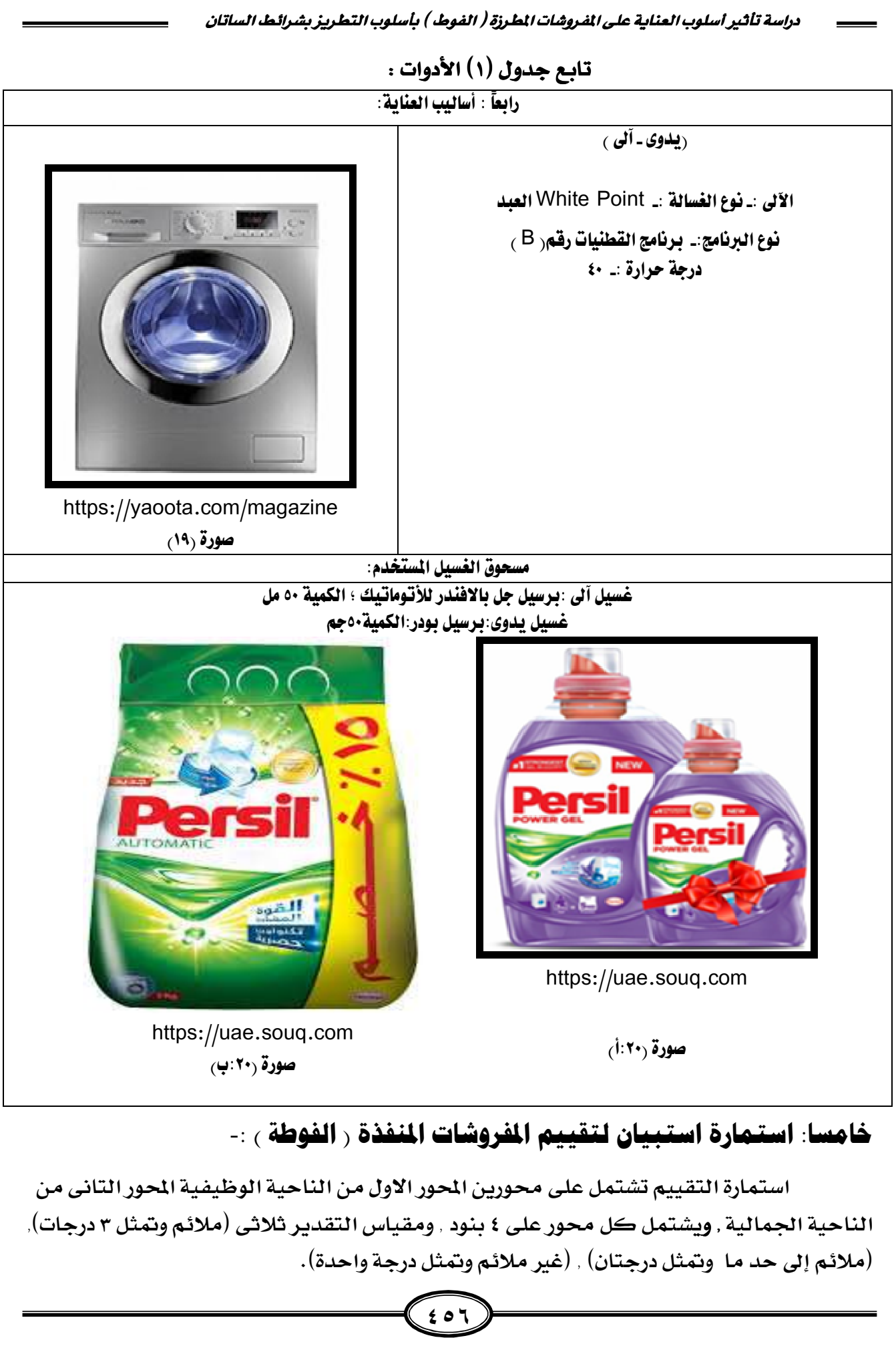




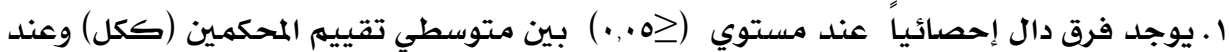

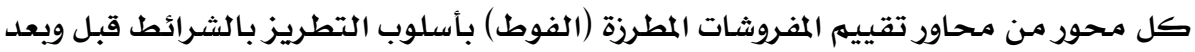

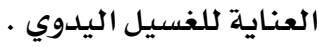

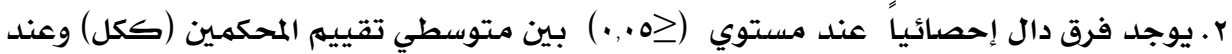

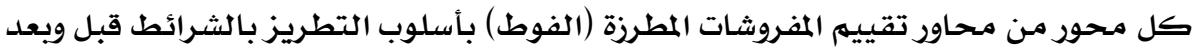

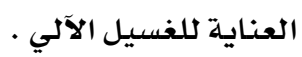

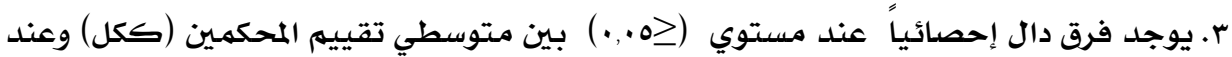

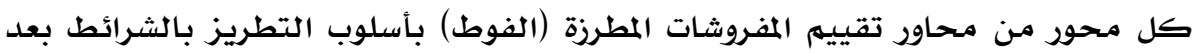
العناية للغسيل اليدوي وبعد العناية للغسيل الآلي.

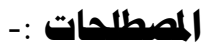

مفهوم التطريز Embroidery:-

هو عبارة عن زخرفة القماش بعد أن يتهم نسجه بواسطة إبرة خاصدة يختلف سمكها وطولها

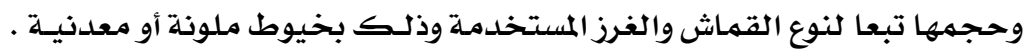
والتطريز إسهم أعجمي أشتق من الكلمة الفارسية ( طرازيدان) وهي ترادف الكلمهة

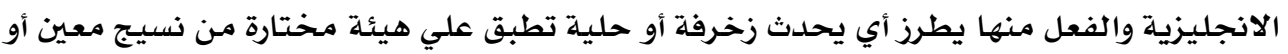

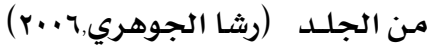
التطريز اليدوي Hand embroidery:

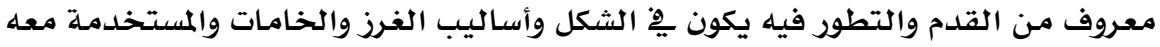

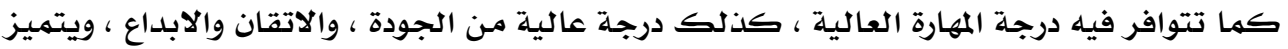

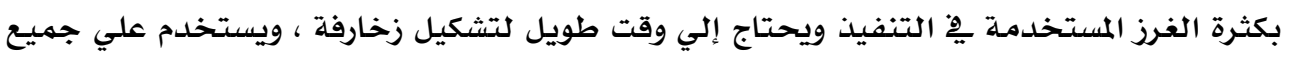

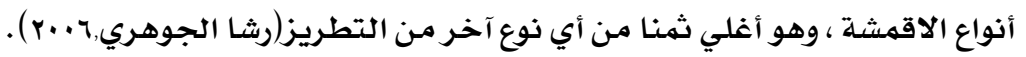
أساليب:مفـردها أسلــوب Method:ـ الأسلوب : الطريق - الفن يِّ القول والعمل وهو طريقة للأداء يِّ مجال الفنون .

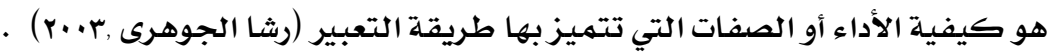
أسلوب العناية بالمفروشات Furniture care methed يعني أسلوب العناية بالمفروشات الحفاظ عليها أطول فترة ممكنة محتفظة برونقها وشكلها

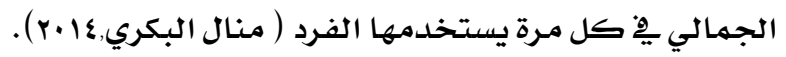




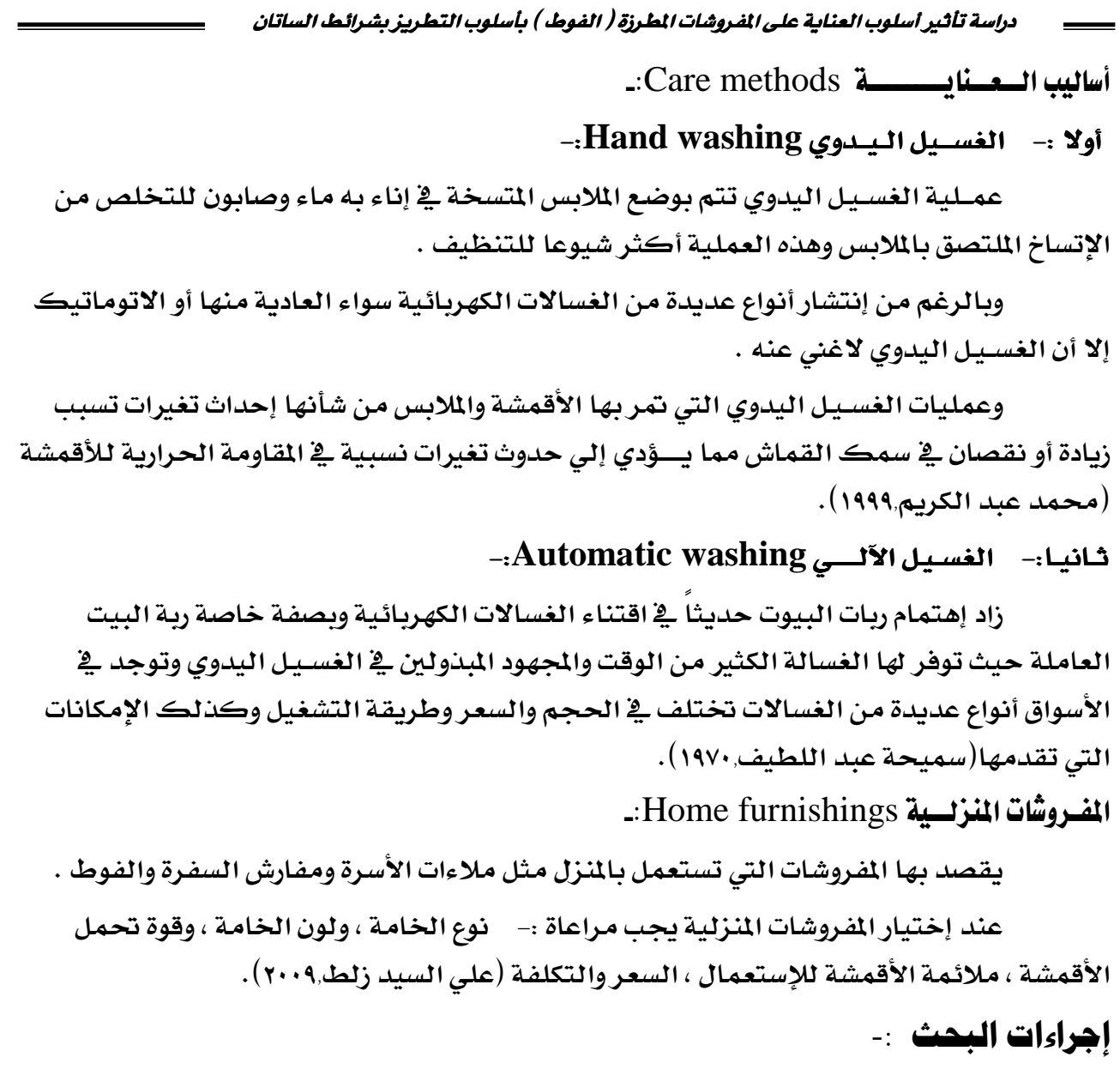

ا ـ الاطلاع على الدراسـات المرتبطة بهحاور البحث المتمثلة يخ (التطريزبشرائط الستان -

المفروشات ،طرق العناية بهما ).

r . تنفيذ أسلوب التطريزعلى المفروشات (الفوط) وفقا للخطوات الأتية: أ- شراء فوط (سادة) بمقاسات متعلدة:

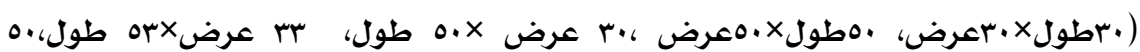

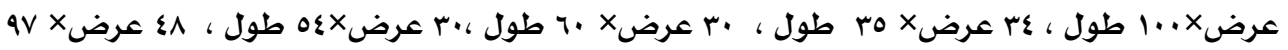

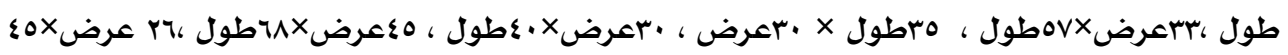
طول ).

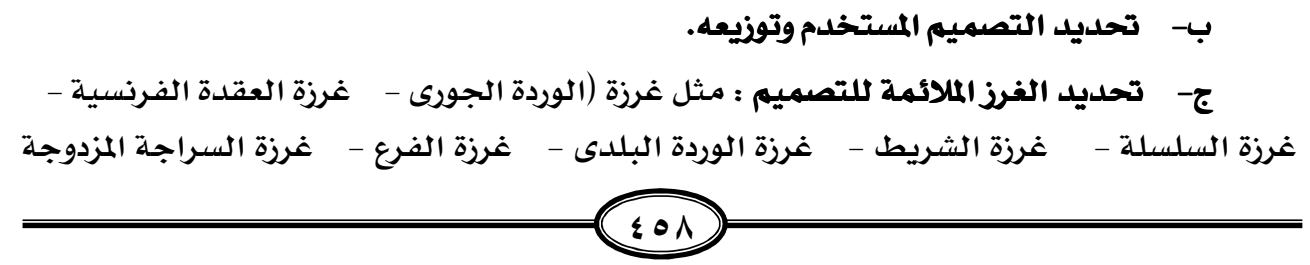


- غرزة الحشو - غرزة التثبيت - غرزة زهرة الربيع - غرزة الوردة الفستقة - فرع ضفيرة غرزة الوردة المفتوحة).

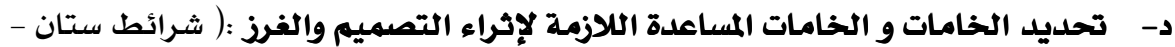

شرائط أورجانزا - خيط كتون بارلية - خيط سراجة - استرس - خرز - شهع ).

ذ- تحليد ألوان الشرائط وعروضها (أخضر غامق ، أزرق ، أحمر غامق ، أصفر، برتقالى ،

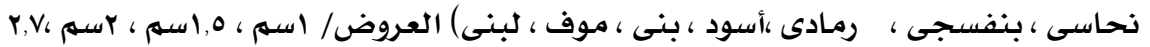

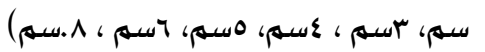

$$
\begin{aligned}
& \text { ر- بباعة التصميم المستخلم بواسطة كريون القماش على الفوطة. } \\
& \text { ز- تنفيذ غرز التطريز بالشرائط على الفوط وهى على النحو التالي : }
\end{aligned}
$$

الغرز المستخدمـة ِيْ تطريز المفروشات(الفوط) بإستخدام شـرائط الستان وطريقة العمل

$$
\text { كما هو موضتح بالصور: }
$$

اـ غرزة الشريط :

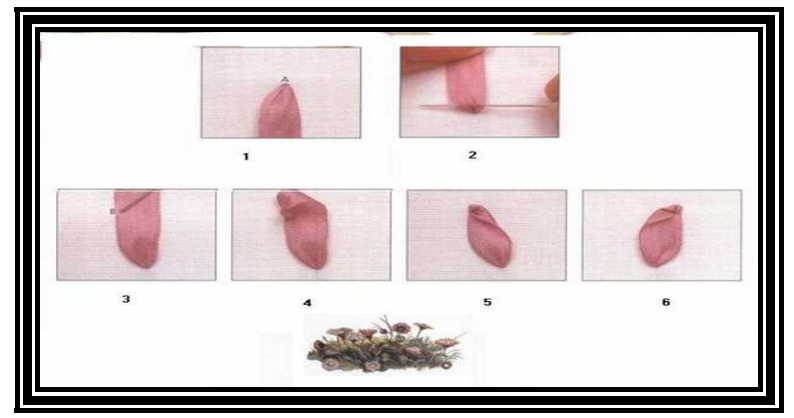

http://www.bntmofeid.com/vb/showthread.php?t=2878

( ) ( ) ( )

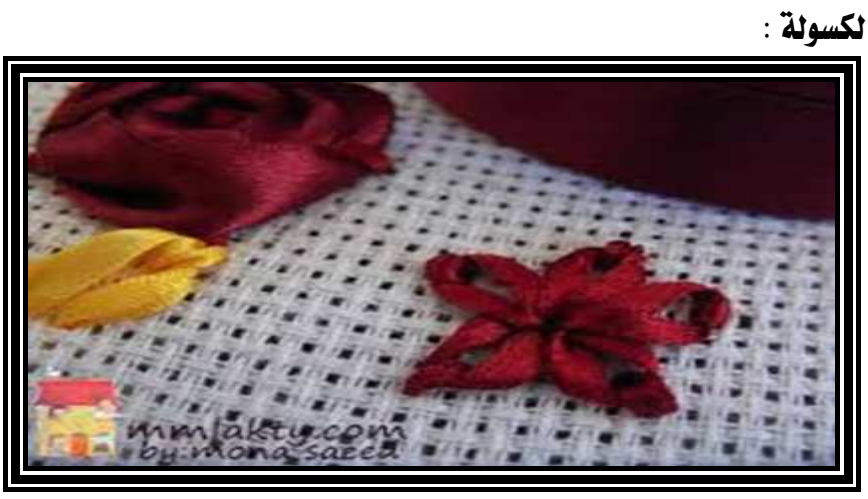

https://i2.wp.com/www.mmlakaty.com/wp-content/uploads/2014/07/48-

e1404582499202.jpg?W=450\&ssl=1

صورة (rr) 
"بـغرزة العقدة الفرنسية لتطريز الشريط (الشرائط):

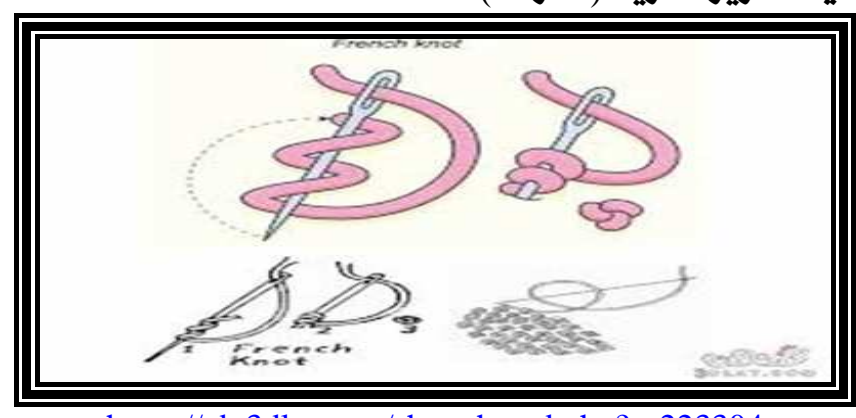

https://vb.3dlat.com/showthread.php?t=223304

صورة (rr)

كـ غرزة الفرع فى تطريز الشرائط:

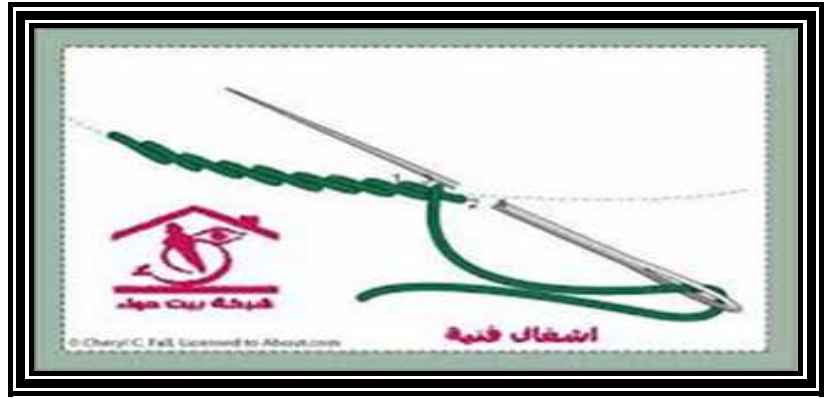

https://forum.hawahome.com/t408090.html

صورة (r )

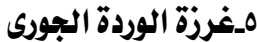

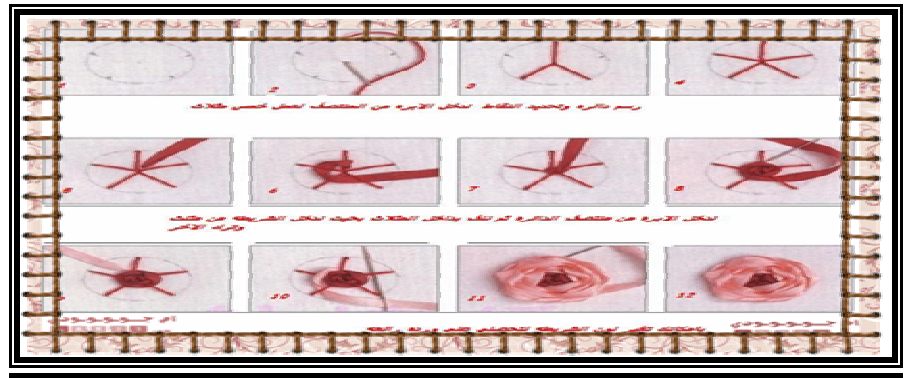

http://crochet-amany.blogspot.com/2011/04/blog-post 514.html

صورة ( ) ( ) ) 


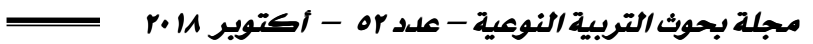




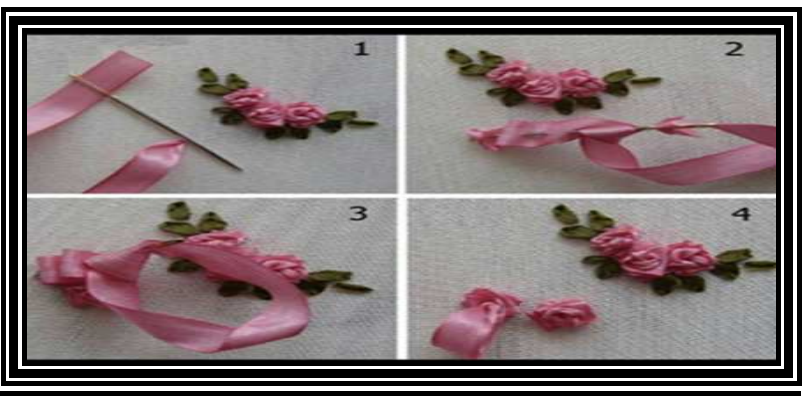

https://dzh.univanet.com/page/834

صورة (r)

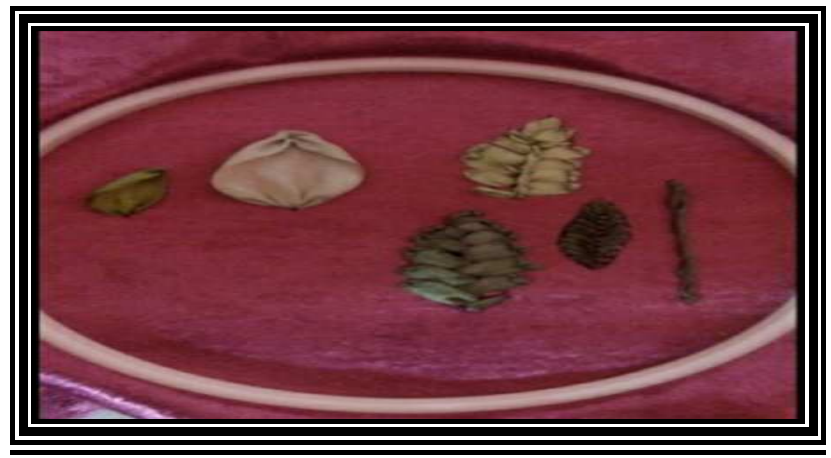

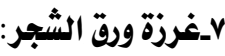

https://www.youtube.com/watch?v=mC5GSNltMVg

(rv) صورة

يـ غرزة الوردة البلدى: - مي

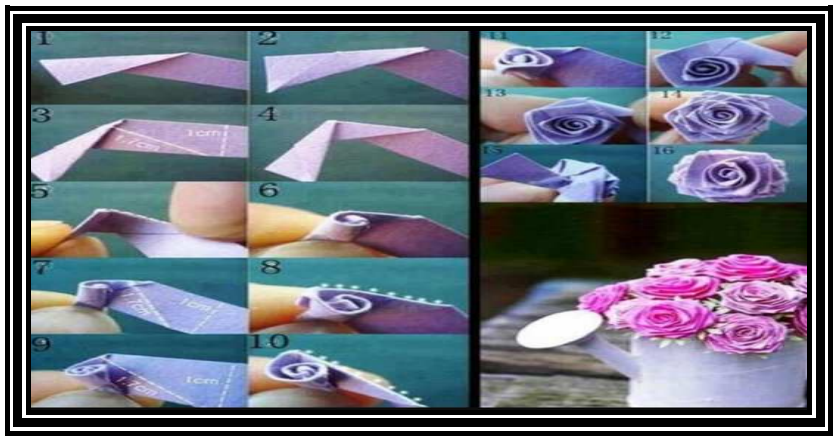

https://www.hawaaworld.com

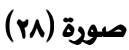




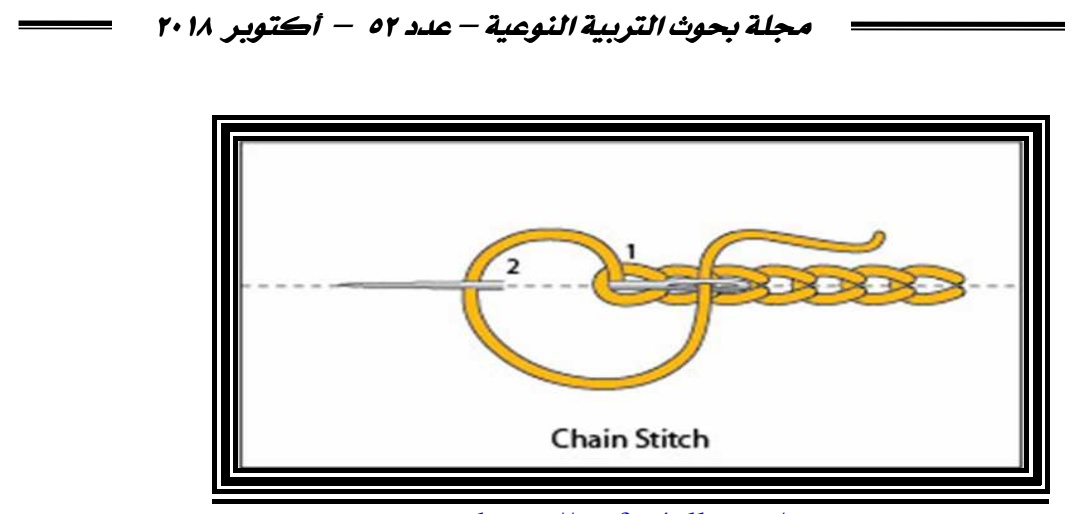

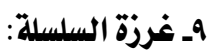

https://crafty4all.com/

صورة (ra)

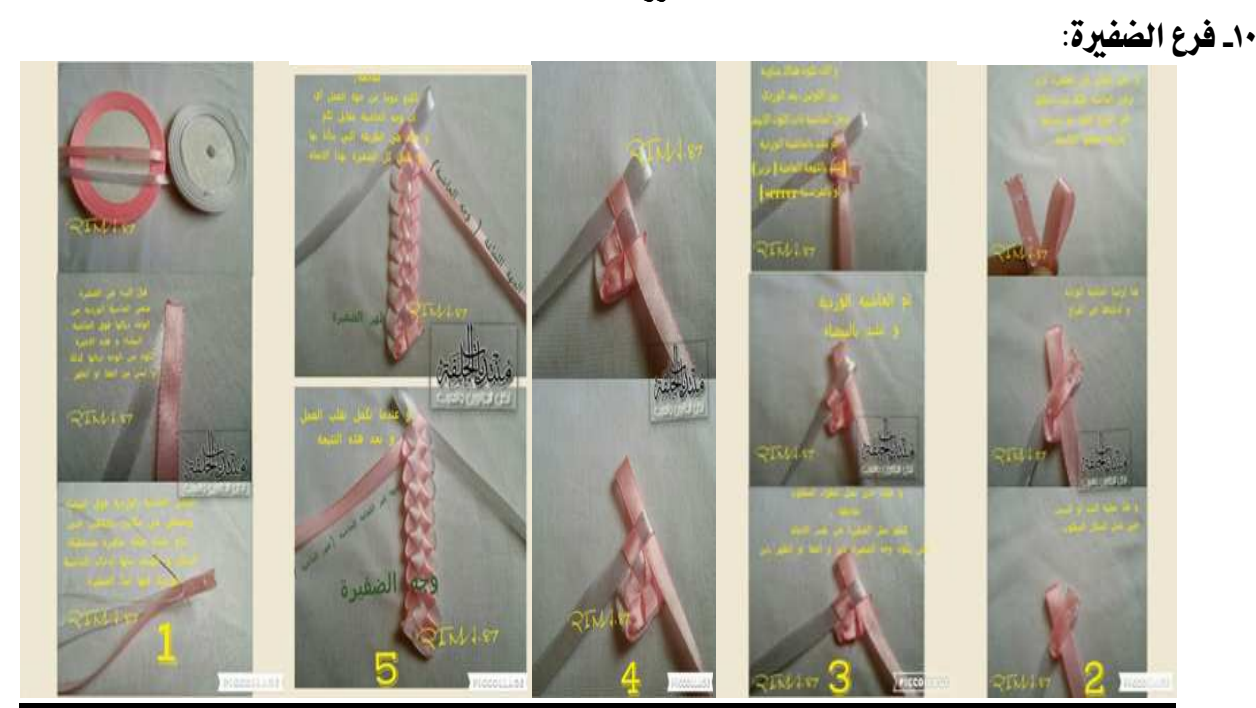

http://www.djelfa.info/vb/showthread.php?t=2016653

صورة) •r(r)

الخاهات المساعدة اللازمة لإثراء التصميم والغرز: الخرز:

طريقة العمل

1- يتم تحديد الخرز المطلوب بالشكل المطلوب وبالكمية المناسبة علي حسب المساحة التي يتم

$$
\text { اضافته إليها. }
$$

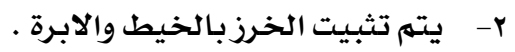

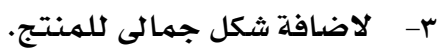




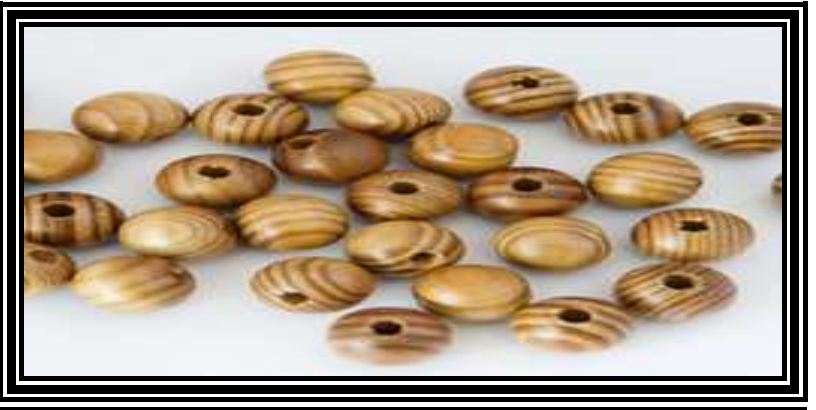

https://www.google.com/search

صورة (r)

\section{الفصوص الكريستال (الاستزس) \\ طريقة العمل}

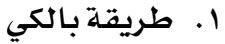

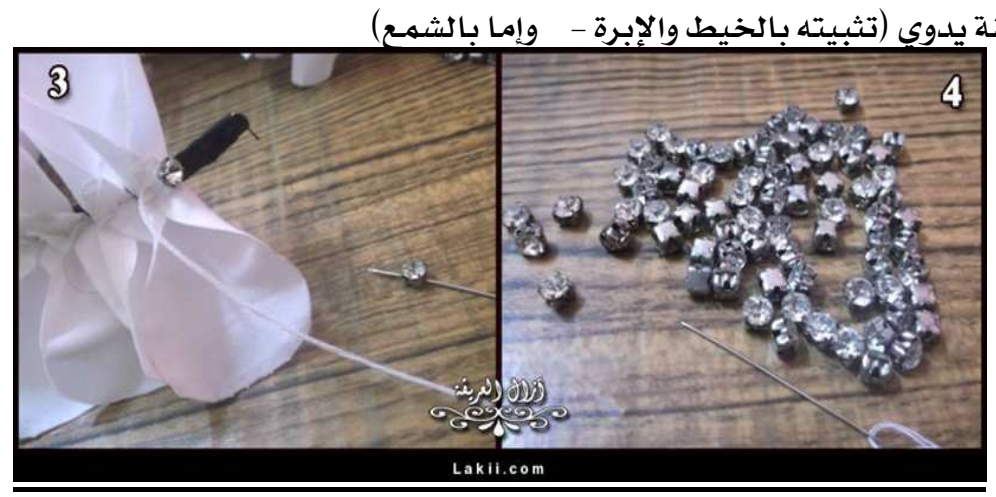

http://www.lakii.com/img/free/Dec12/nV4Jwj6oxPD.jpg

صورة(rr) 


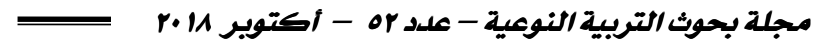

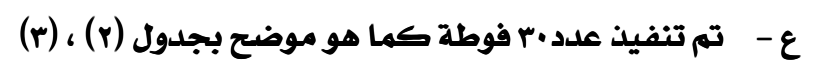

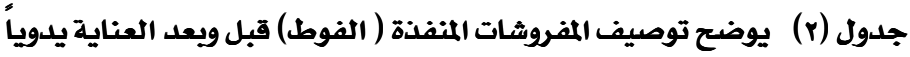

\begin{tabular}{|c|c|c|c|}
\hline التوصيف & التصميه بعد الفسيل & التصميم قبل الغسيل & A \\
\hline 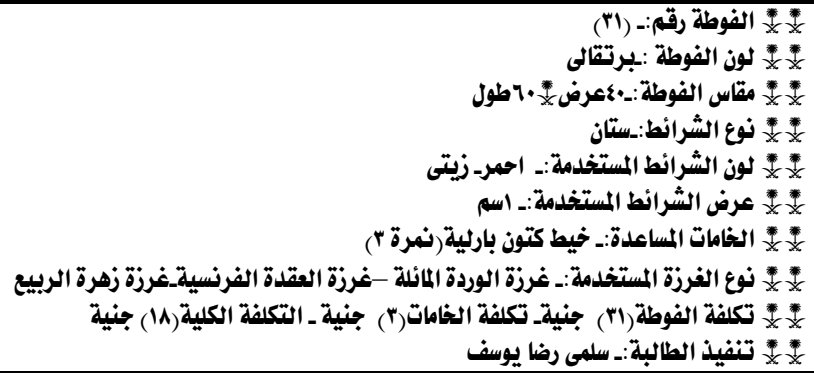 & & & \\
\hline 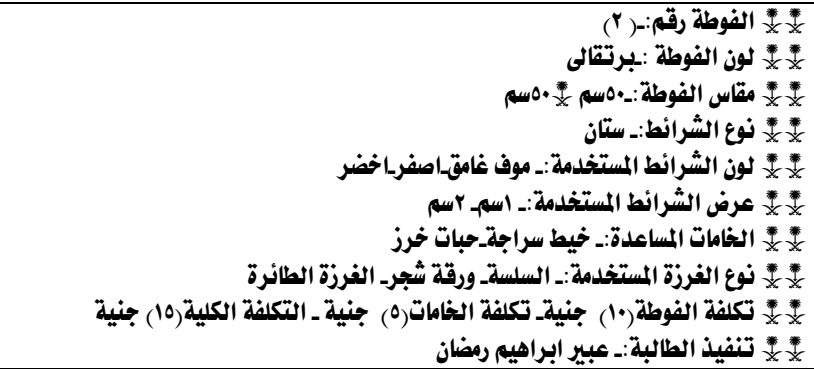 & & 0 & r \\
\hline 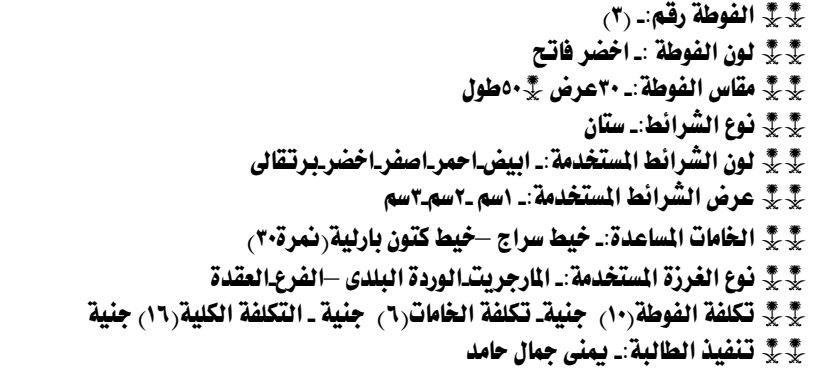 & $2, t=$ & $20 x+6$ & $r$ \\
\hline 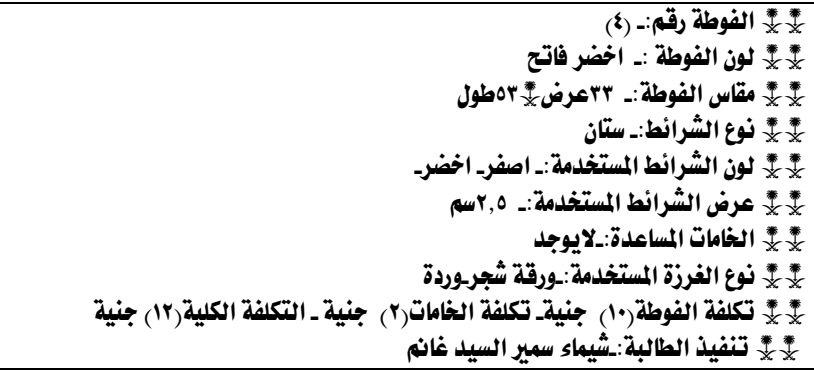 & $=3$ & $=8$ & $\xi$ \\
\hline
\end{tabular}




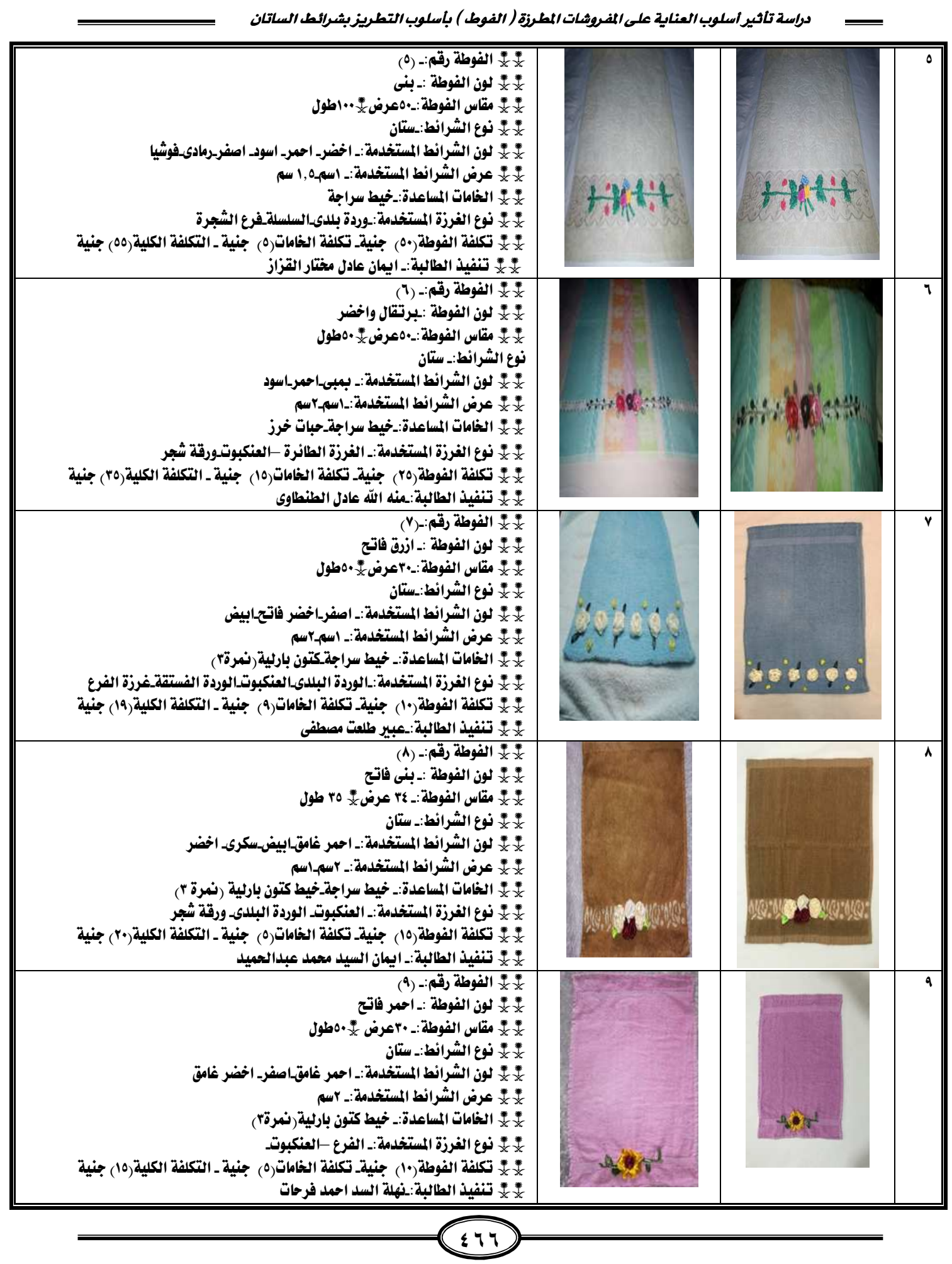




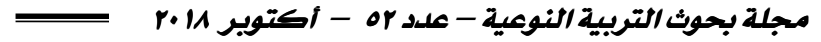

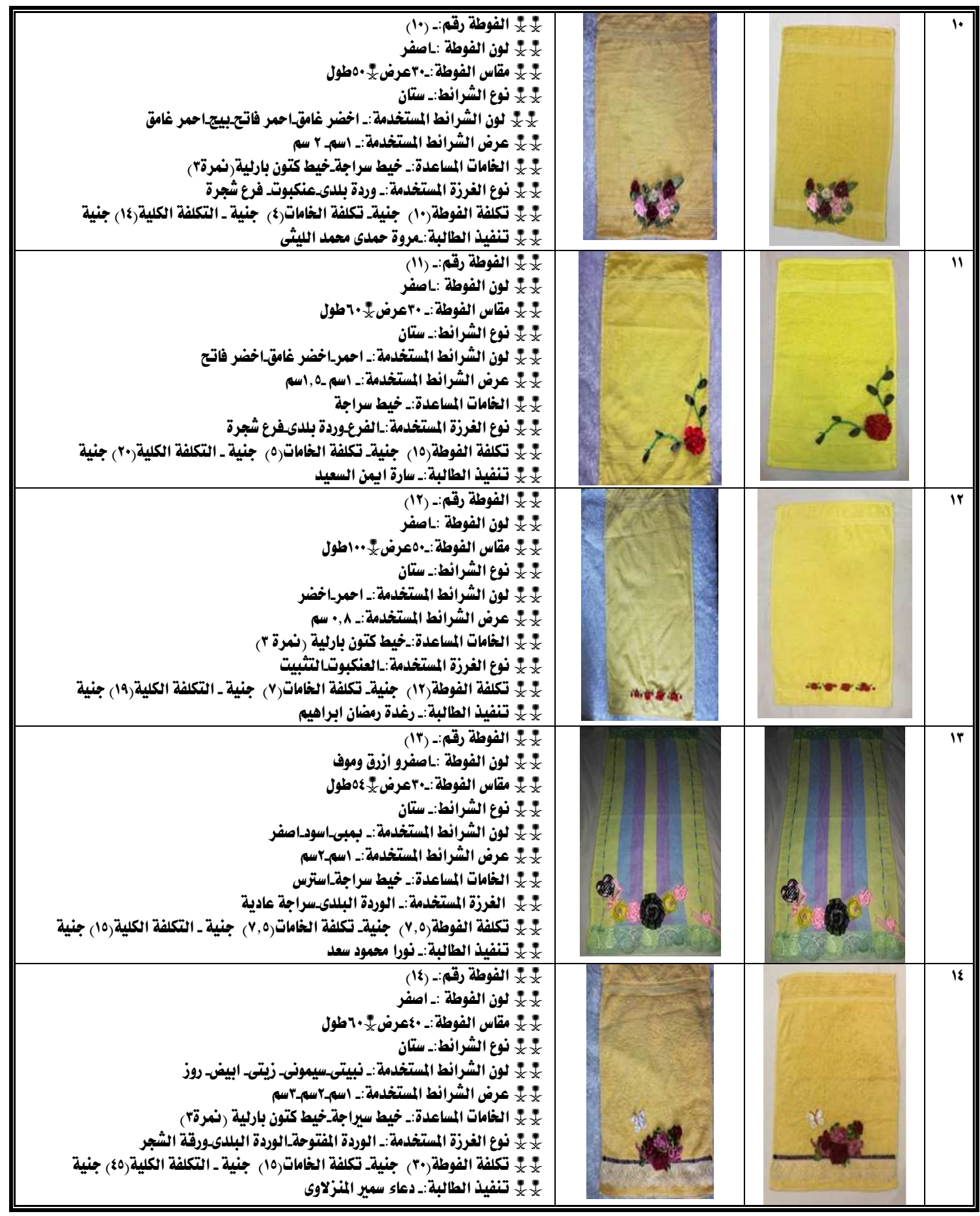




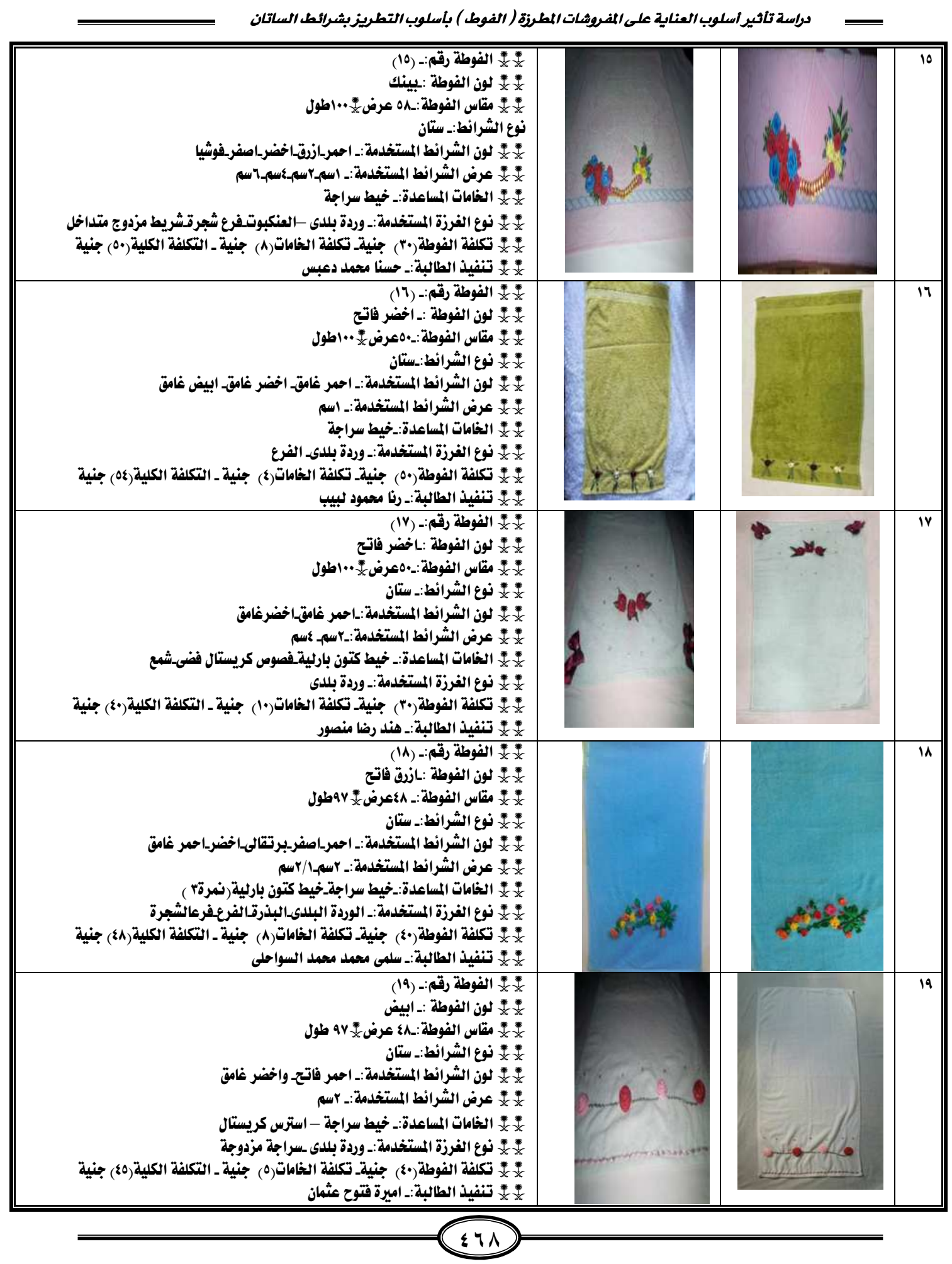




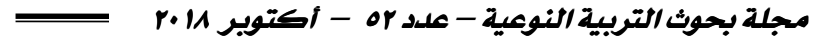

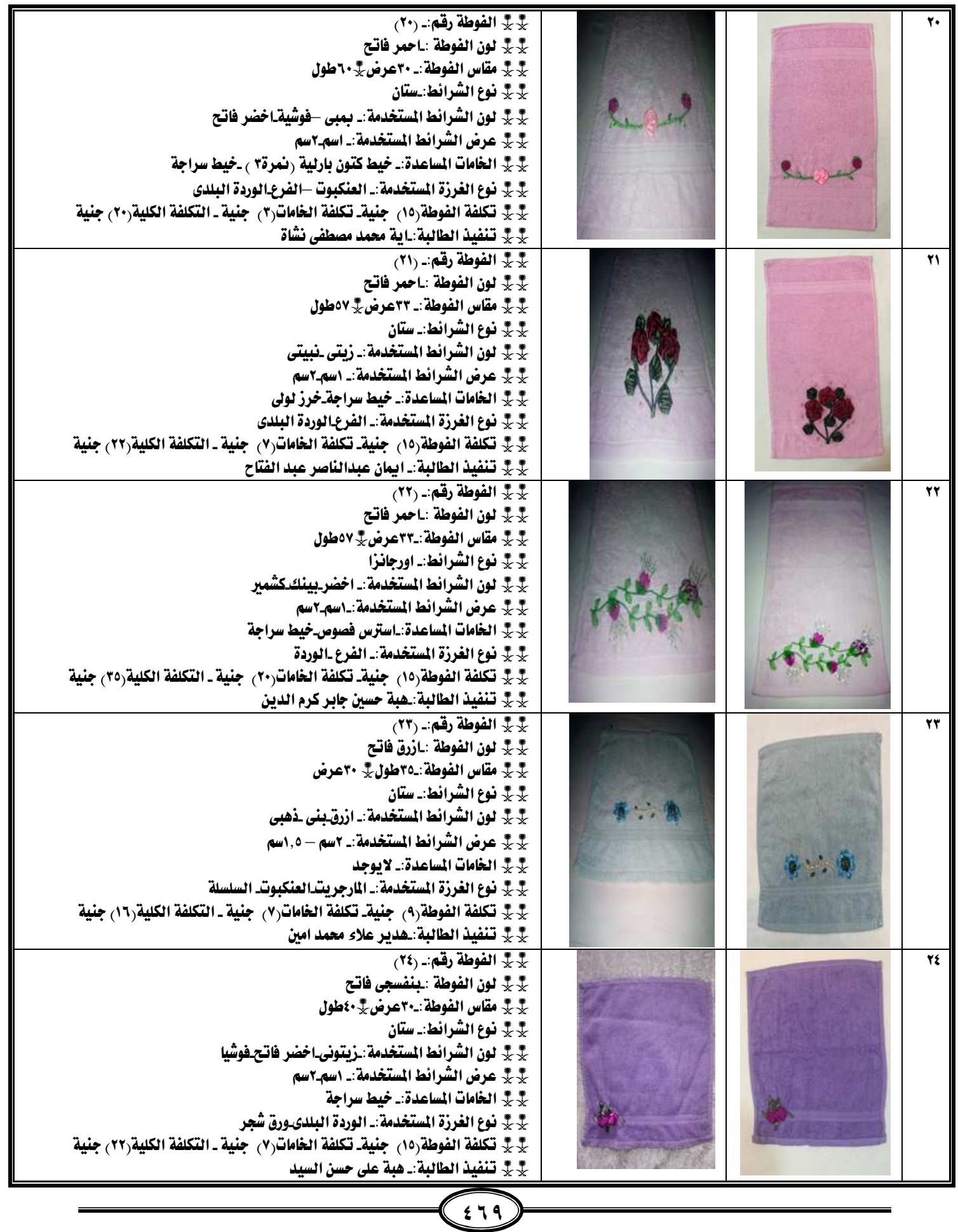




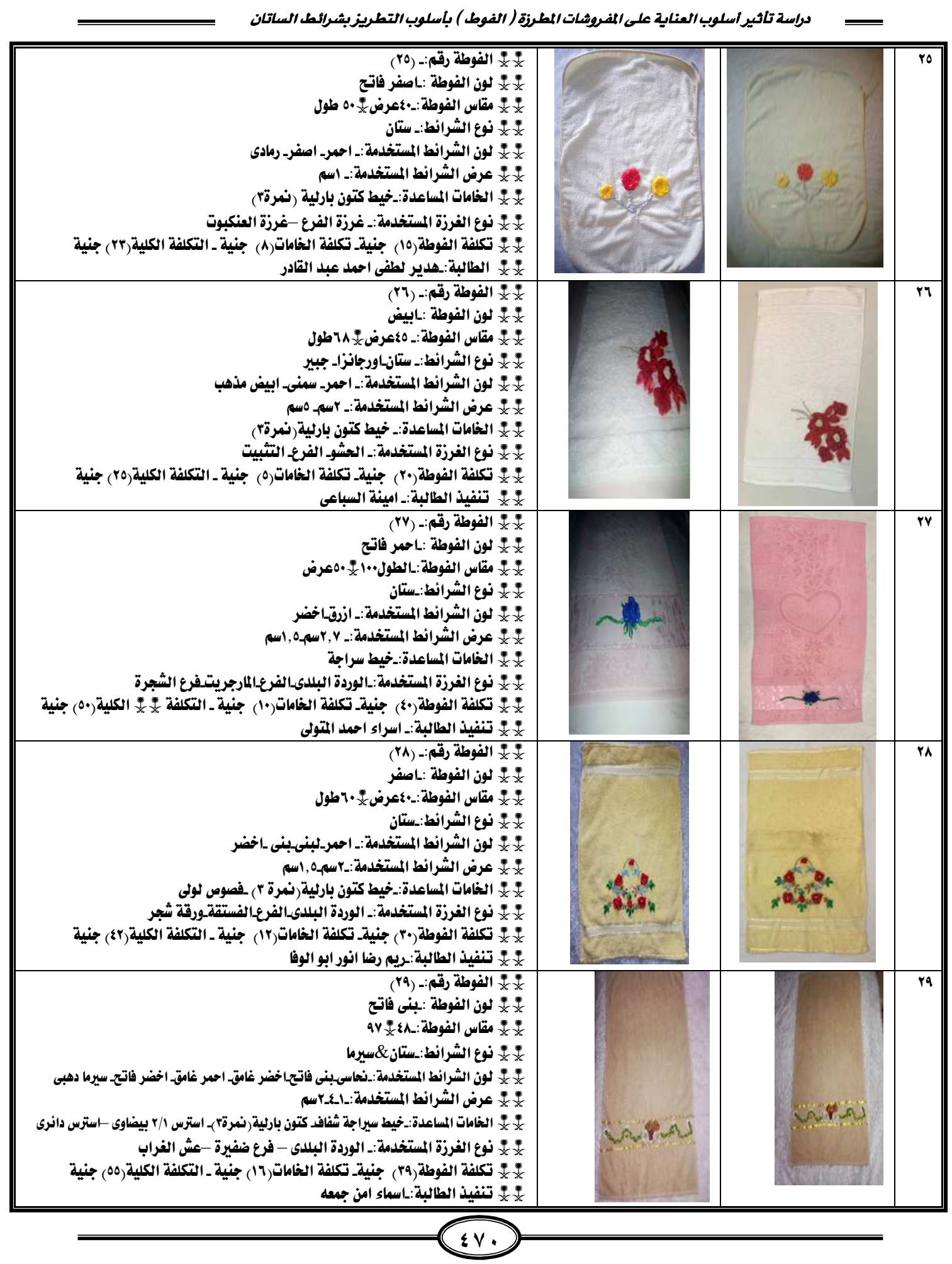




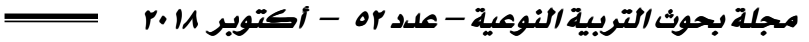

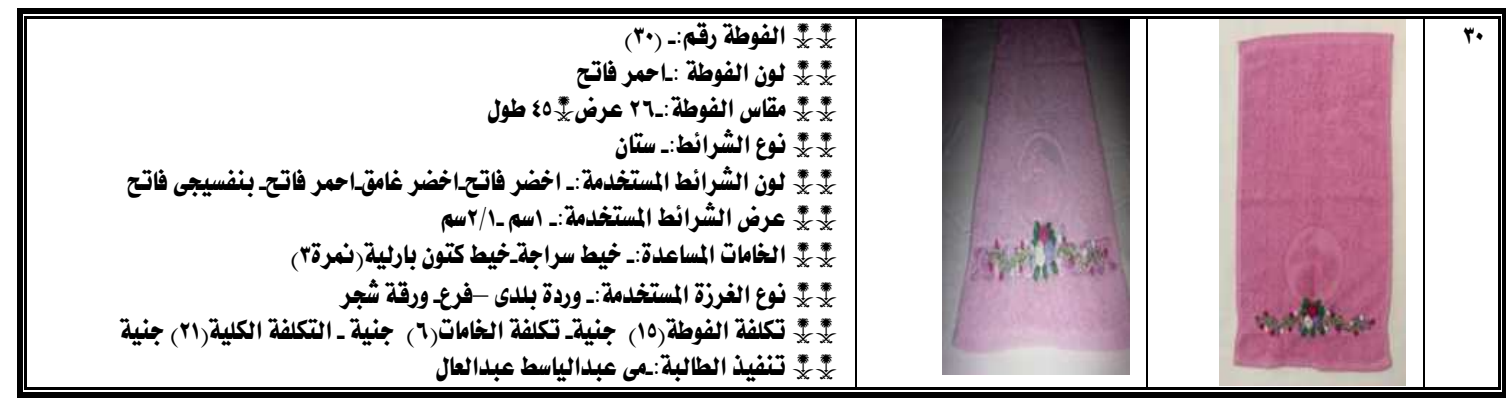

$$
\text { غ - إعداد استمارة لتقييم المفروشات المنفذة (الفوط) قبل وبعد العناية : }
$$

اشتملت الاستمارة على محورين: الناحية الوظيفية ،الناحية الجمالية ،واشتمل كل محتور

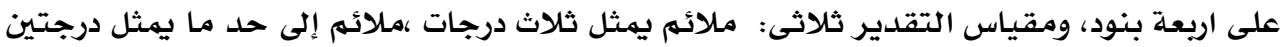

$$
\text { غير ملائم يمثل درجة اربة بنود، ومقياسن التقدة }
$$

ف- تم عرض الاستمارة على السادة المحكمين وعددهم مـ محكم في مجال التخصص لقياس

$$
\text { صدق وثبات الاستمارة. }
$$

م - تم عرض المفروشات المنفذة (الفوط) قبل العناية على السادة المحكمين وعددهم ل1 1 محكم

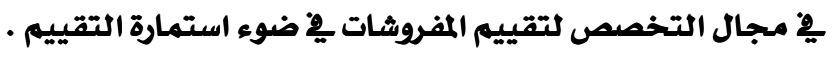

هـ - اجراء عملية العناية باسلوبي الغسيل(اليدوي والالى) بمعدل خمسة عشر فوطة لكل

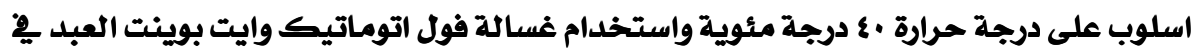

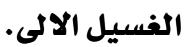

و- تم عرض المفروشات المنفذة (الفوط) بعد العناية على السادة المحكمين وعددهم ل1 1 محكم فى مجال التخصص لتقييم المفروشات فى ضوء استمارة التقييم.

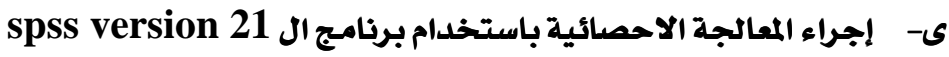

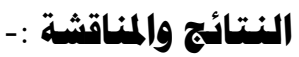
تقنين الأدوات (الصلدق والثبات) أولاً: استبييان تقيييم المحكمين للمفروشات المطرزة قامت الباحثات بإعداد استبيان موجه للمتخصصين بهجال المانيان المابس والنسيج - لتحكيم

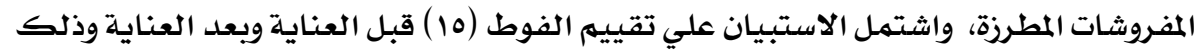

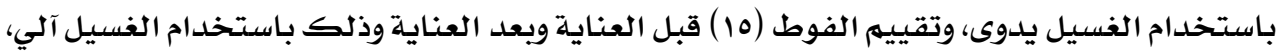

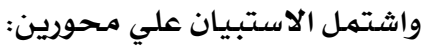
المحور الأول: تحقيق الناحية الوظيفية وتتضمن (ع) عبارات. المحور الثاني: تحقيق الناحية الجمالية وتتضمن (ع) عبارات. 
وقد استخدم ميـزان تقدير ثلاثي المستويات بحيث تعطي الاجابـة مناسـب (ثلاث درجـات)

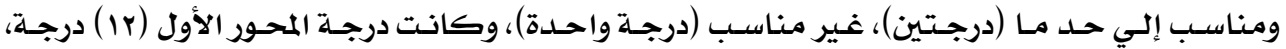

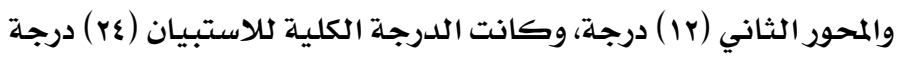
صدق محتوي الاستبييان: صدق المحكمين:

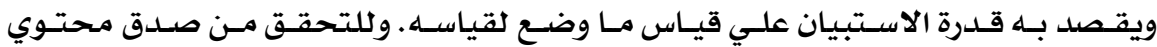

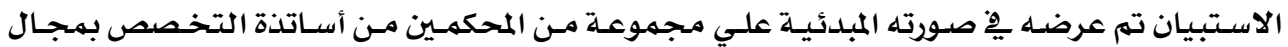

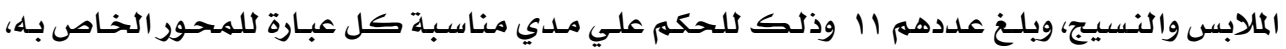

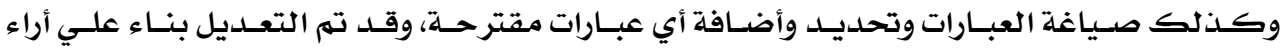

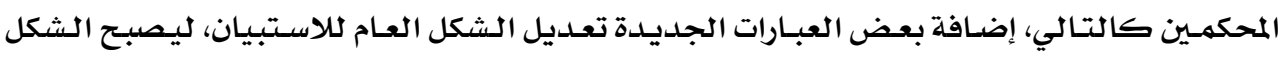
النهائي لها الصلد باستخدام الاتساق الداخلي بين الدرجة الكلية لكل محور والدرجة الكلية للاستبيان:

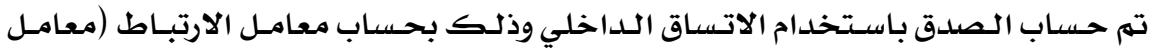

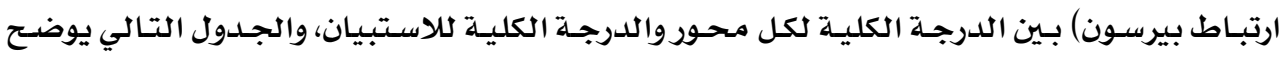
ذلك:

جدول( ع) : قيم معاملات الارتباط بين درجة كل محورودرجة الاستبيان

\begin{tabular}{|c|c|c|}
\hline الدلاكة & الارتباط & \\
\hline$\bullet, \cdot 1$ & $\cdot, 90$ & المحور الأول: الناحية الوظيفية \\
\hline$\cdot, \cdot 1$ & $\cdot, 4 \varepsilon$ & المحور الثاني: تحقيق الناحية الجمالية \\
\hline
\end{tabular}

يتضح من الجدول السـابق أن معاملات الارتباط كلها دالة عند مستوي ا +. • لاقترابها مـن

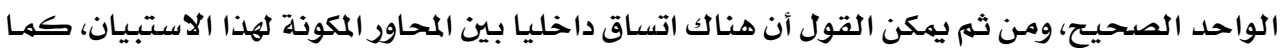

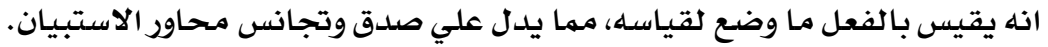

\section{ثبات الاستبيان}

يقصد بالثبات دقة الاختبار يِّ القياس والملاحظة، وعدم تناقضهـ مـع نفسه، واتسـاقه واطراده

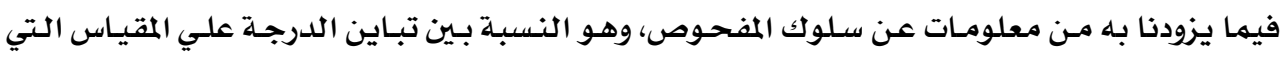
تشير إلي الأداء الفعلي للمفحوص، وتهن معلومات حساب الثبات عن طريق: Alpha Cronbach

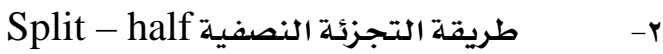




\begin{tabular}{|c|c|c|}
\hline التجزئة النصفية & معامل ألثا & \\
\hline$\bullet, q r r-\bullet, \Lambda \cdot r$ & $\cdot, \Lambda \cdot 9$ & المحور الأول: الناحية الوظيفية \\
\hline$\cdot, 9 r \varepsilon-\cdot, \wedge \cdot 9$ & $\cdot$, Alr & المحور الثاني: تحقيق الناحية الجمالية \\
\hline$\cdot, 9 Y O_{-}+, 1 \cdot 0$ & $\cdot$, Al. & ثبات الاستبيان ككل \\
\hline
\end{tabular}

يتضح من الجدول السـابق أن جميـع قيهم معاملات الثبـات، معامـل ألفـا، التجزئـة النصفية، دالة عند مستوي ا +, • مما يدل علي ثبات الاستبيان. هناقشة النتائج التي توصل إليها لندا البحث: الفرض الأول للتحقق من صحة الفرض الأول من فروض البحث والذي ينص علي: " يوجد فرق دال

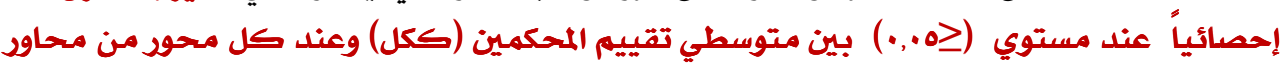
تقييم المفروشات المطرزة (الفوط) بأسلوب التطريز بالشرائط قبل وبعد العناية للغسيل الئوسئ اليدوي.

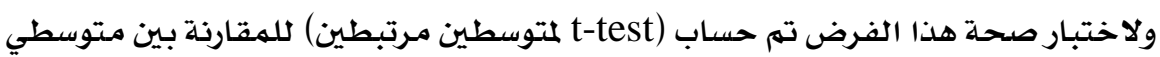

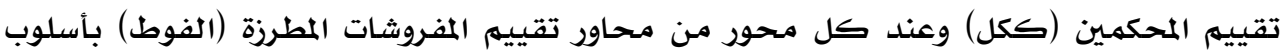

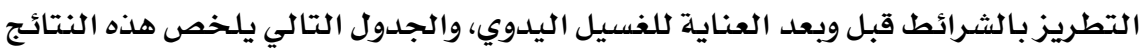
جدول (ج) يوضح نتائج اختبار "ت" للمقارنة بين المتوسطين القبلي والبعدي لتقييم المحكمين (ككل) وعند كل محور من محاور تقييم المفروشات المطرزة (الفوط) بأسلوب التطريز

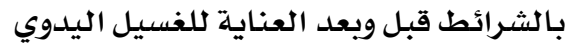

\begin{tabular}{|c|c|c|c|c|c|c|}
\hline مستوي الدلالة & قيمة "ت" & درجة الحرية & الانحراف المعياري & المتوسط & التطبيق & المحور \\
\hline \multirow{2}{*}{ دالة } & \multirow{2}{*}{9.853} & \multirow{2}{*}{14} & 2.49 & 127.73 & قبل العناية & الناحية \\
\hline & & & 13.11 & 91.53 & بعد العناية & الوظيفية \\
\hline \multirow{2}{*}{ دالة } & \multirow{2}{*}{9.433} & \multirow{2}{*}{14} & 6.57 & 123.13 & قبل العناية & الناحية \\
\hline & & & 8.01 & 96.07 & بعد العناية & الجمالية \\
\hline \multirow{2}{*}{ دالة } & \multirow{2}{*}{11.654} & \multirow{2}{*}{14} & 7.79 & 250.87 & قبل العناية & \multirow{2}{*}{ التقييي (ككل) } \\
\hline & & & 17.95 & 187.60 & بعد العناية & \\
\hline
\end{tabular}

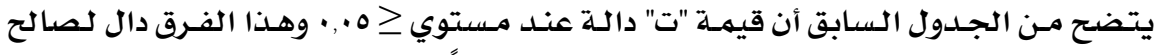

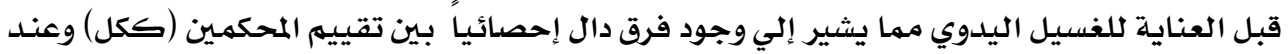

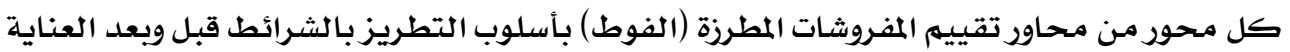

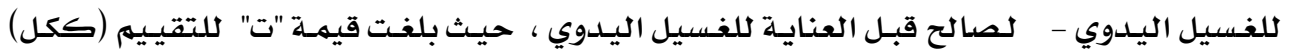

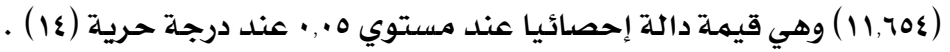




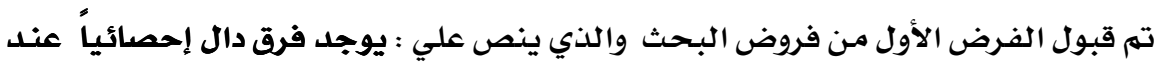

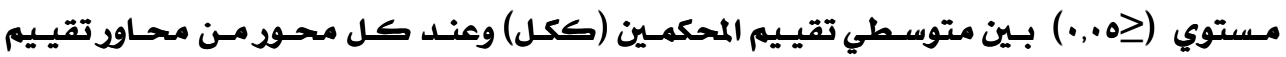

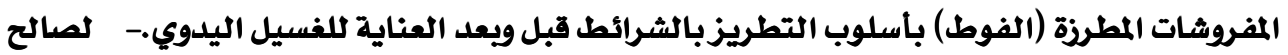
قبل العناية للغسيل اليدويل.

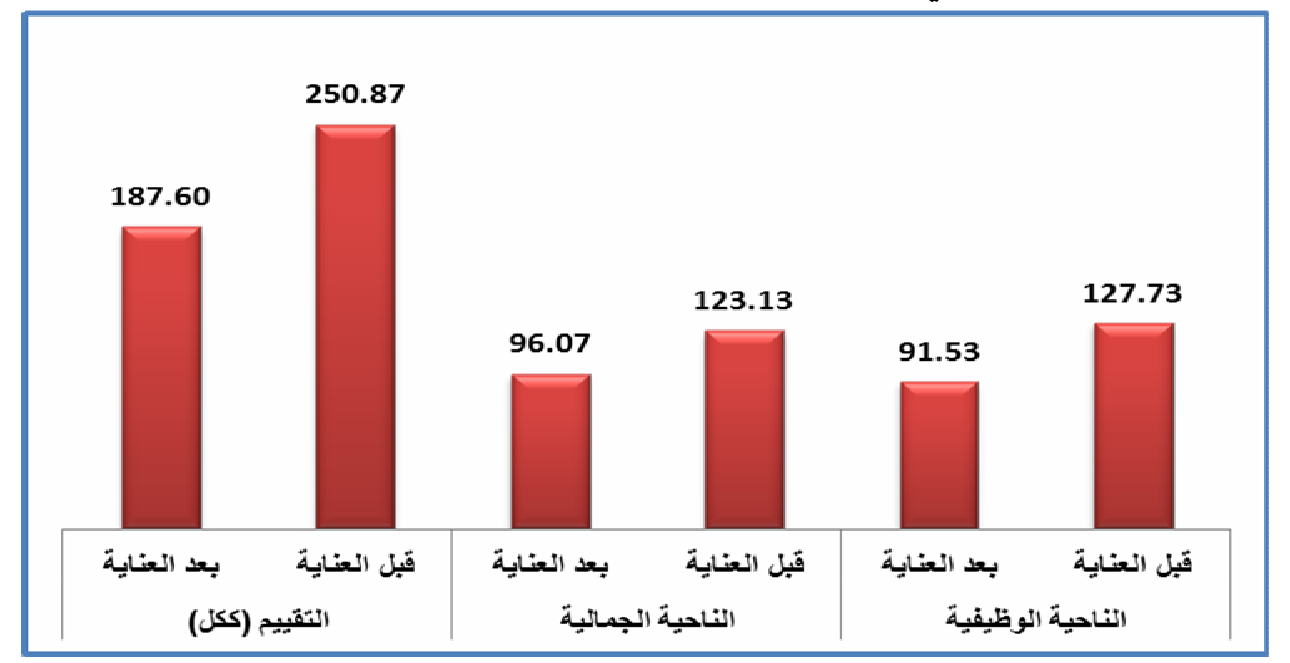

شكل (1) متوسط تقييم المحكمين (ككل) وعند كل محور من محاور تقييم المفروشات المطرزة (الفوط) بأسلوب التطريز

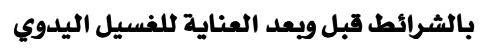

\section{الفرض الثاني}

للتحقق من صحة الفرض الثاني من فروض البحث والذي ينص علي: " يوجد فرق دال

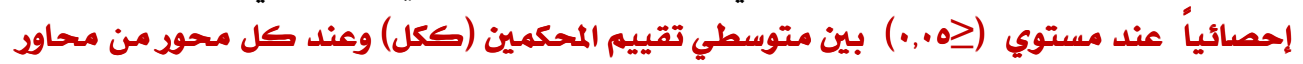

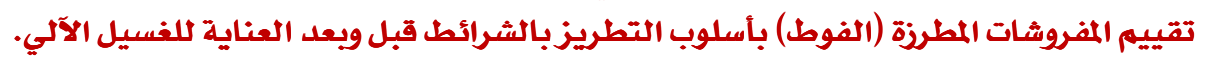

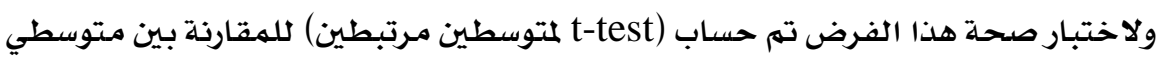

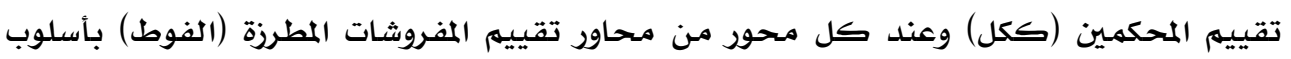

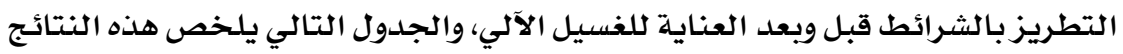




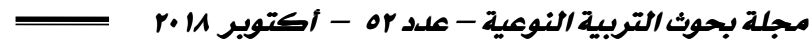

جدول (v) يوضح نتائج اختبار "ت" للمقارنة بين المتوسطين القبلي والبعدي لتقييم المحكمين (ككل) وعند كل محور

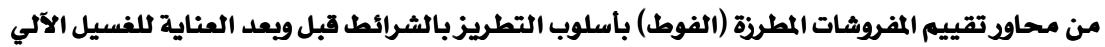

\begin{tabular}{|c|c|c|c|c|c|c|}
\hline مستوي الدلالة & قيمة "ت" & درجة الحرية & الانحراف المياري & المتوسط & التطبيق & المحور \\
\hline \multirow{2}{*}{ دالة } & \multirow{2}{*}{12.460} & \multirow{2}{*}{14} & 3.29 & 126.87 & قبل العناية & الناحية \\
\hline & & & 9.64 & 94.80 & بعد العناية & الوظيفية \\
\hline \multirow{2}{*}{ دالة } & \multirow{2}{*}{10.315} & \multirow{2}{*}{14} & 6.19 & 125.20 & قبل العناية & الناحية \\
\hline & & & 8.80 & 96.93 & بعد العناية & الجمالية \\
\hline \multirow{2}{*}{ دالة } & \multirow{2}{*}{13.197} & \multirow{2}{*}{14} & 7.85 & 252.07 & قبل العناية & \multirow{2}{*}{ التقييم (ككل) } \\
\hline & & & 15.94 & 191.73 & بعد العناية & \\
\hline
\end{tabular}

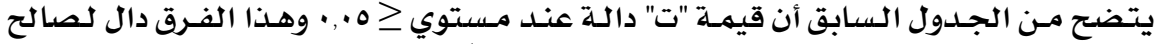

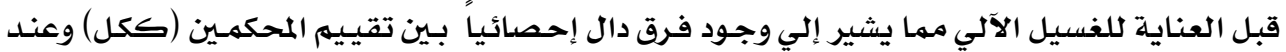

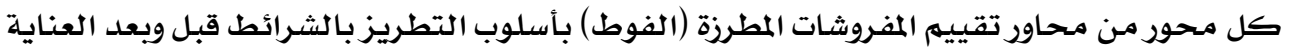

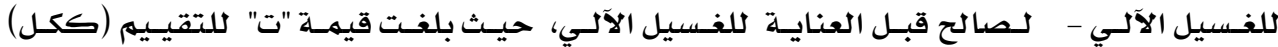

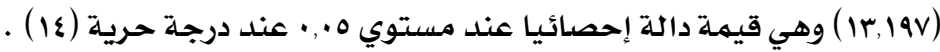

\section{هناقشة الفرض الثاني:}

تم قبول الفرض الثاني من فروض البحث والذي ينص علي : يوجد فرق دال إحصائياً عند

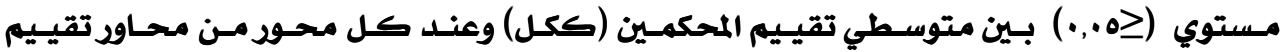

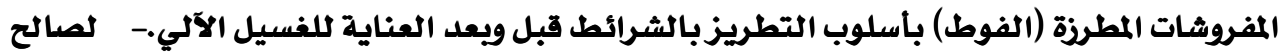
قبل العناية للغسيل الآلي...

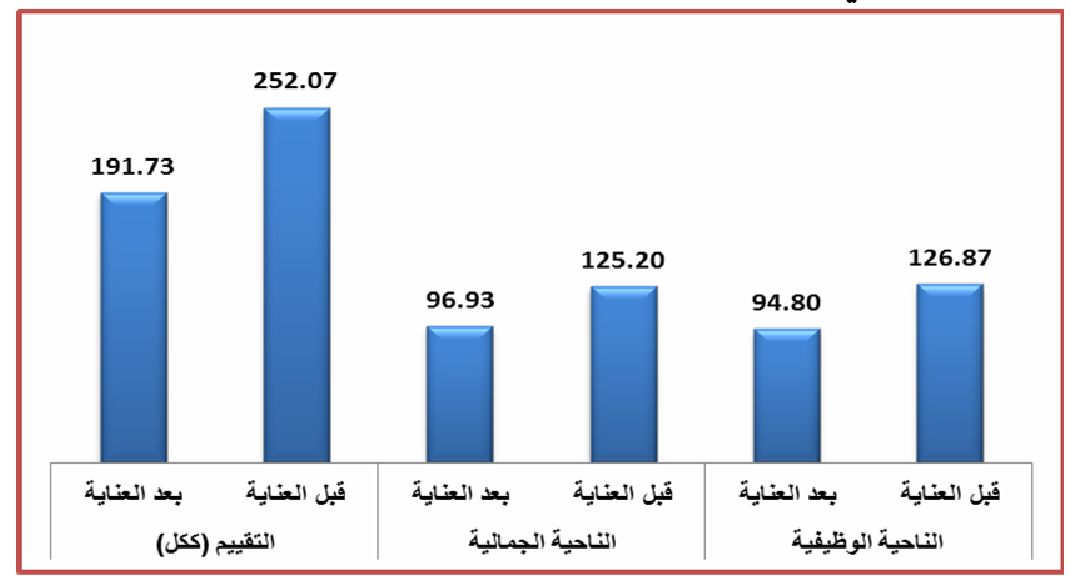

شكل (Y) متوسط تقييم المحكمين (ككل) وعند كل محور من محاور تقييم المفروشات المطرزة (الفوط) بأسلوب التطريز بالشرائط قبل ويعد العناية للغسيل الآلي محئ موني 


\section{دراسة تأثيراسلوب العناية على المفروشات المطرزة ( الفوط ) باسلوب التطريزبشرائط الساتان بـ \\ الفرض الثالث}

للتحقق من صحة الفرض الثالث من فروض البحث والذي ينص علي: " يوجد فرق دال

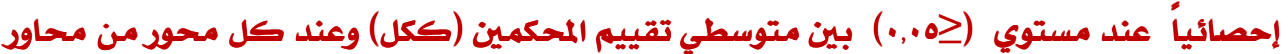

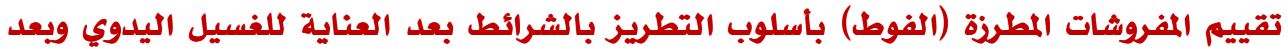

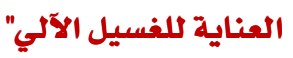

قامت الباحثات بحساب المتوسطات والانحرافات المعيارية لتقييم المحكمين (ككل) وعند

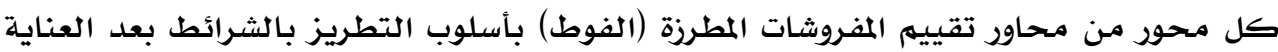

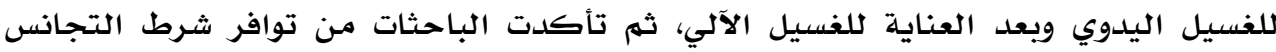

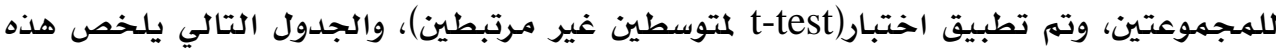

النتائج.

جدول (^) قيمة " ت " ودلالتها الإحصائية للفرق بين متوسطي تقييم المحكمين (ككل) وعند كل محور من محاور

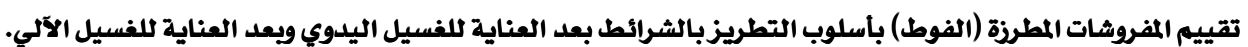

\begin{tabular}{|c|c|c|c|c|c|c|}
\hline مستوي الدلالة & قيمة "ت" & درجة الحرية & الانحراف المعياري & المتوسط & الغسيل & المحور \\
\hline \multirow{2}{*}{ غير دالة } & \multirow{2}{*}{.777} & \multirow{2}{*}{28} & 13.11 & 91.53 & اليدوي & \multirow{2}{*}{ الناحية الوظيفية } \\
\hline & & & 9.64 & 94.80 & الآلي & \\
\hline \multirow{2}{*}{ غير دالة } & \multirow{2}{*}{.282} & \multirow{2}{*}{28} & 8.01 & 96.07 & اليدوي & \multirow{2}{*}{ الناحية الجمالية } \\
\hline & & & 8.80 & 96.93 & الآلي & \\
\hline \multirow{2}{*}{ غير دالة } & \multirow{2}{*}{.667} & \multirow{2}{*}{28} & 17.95 & 187.60 & اليدوي & \multirow{2}{*}{ التقييم (ككل) } \\
\hline & & & 15.94 & 191.73 & الآلي & \\
\hline
\end{tabular}

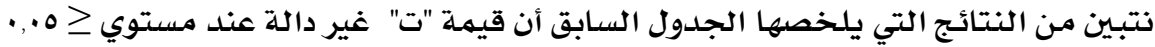

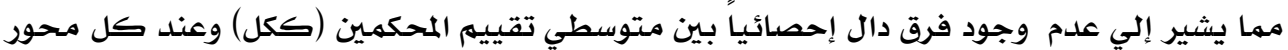

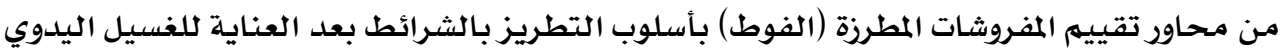
وبعد العناية للغسيل الآلي. هناقشة الفرض الثالث:

تم رفض الفرض الثالث من فروض البحث والذي ينص علي : " يوجد فرق دال إحصائياً

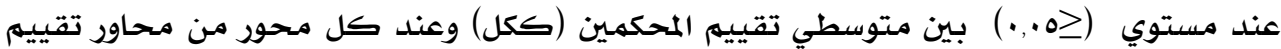

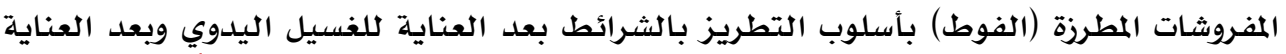

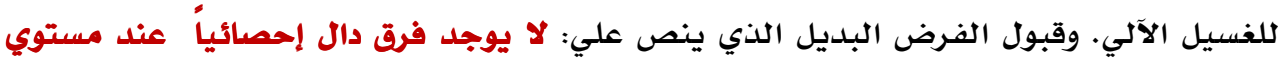

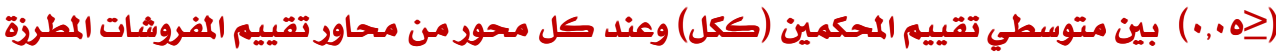

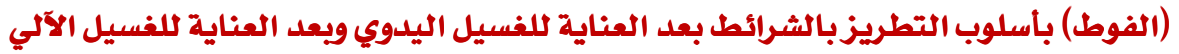




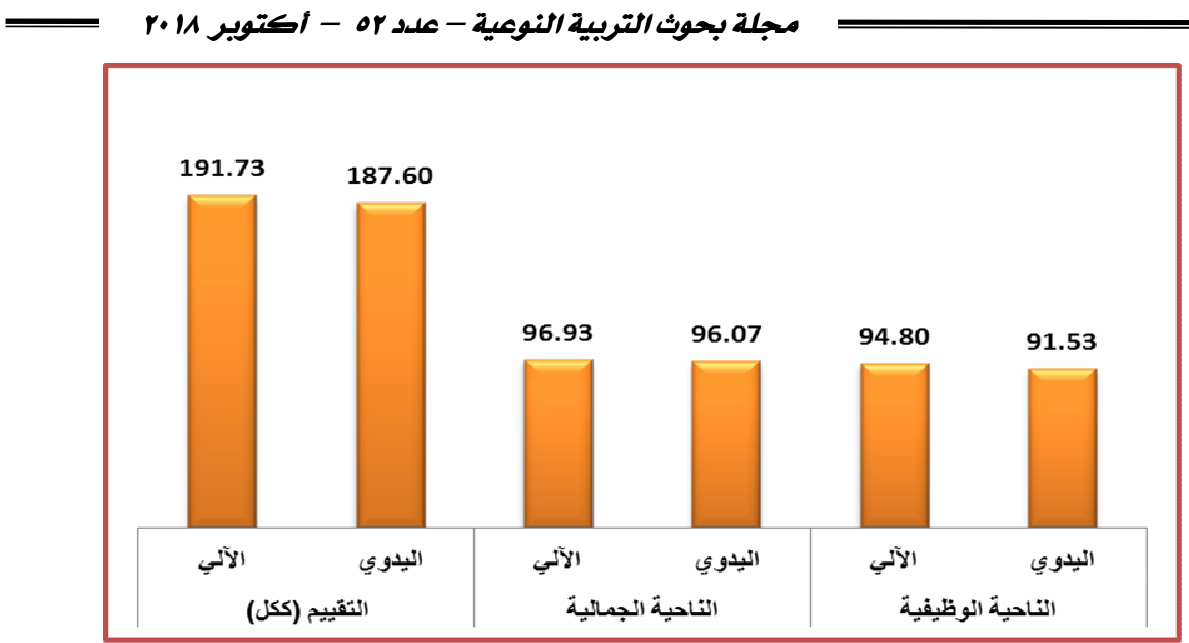

ثكل (r)متوسطي تقييم المحكمين (ككل) وعند كل محور من محاور تقييم المفروثات المطرزة (الفوط) بأسلوب التطريز بالشرائط بعد العناية للغسيل اليدوي وبعد العناية للغسيل الآلي.

التوصيات :- التوعة

ا. التوعية بأهمية العمل على تنمية المهارات اليدوية والفنية فى التطريز بشرائط الساتان على الفى

$$
\text { المفروشات (الفوط). }
$$

r. الاستفادة من نتائج البحث يِّ التطريز بشرائط الساتان لإثراء القيمة الجمالية للمفروشات

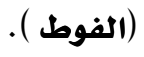

ץ. الاهتمام بمجال التطريز اليدوي لأنه من أهم الفنون المؤثرة يِّ المجال الصناعي.

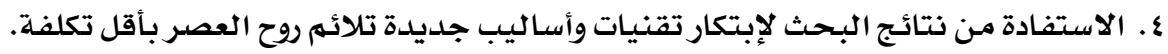

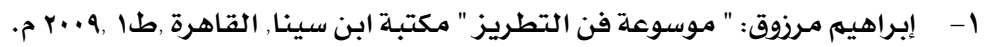

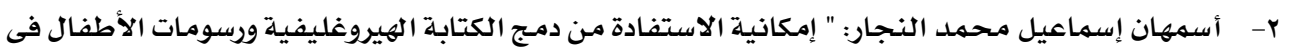

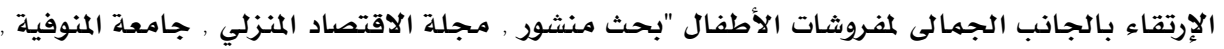

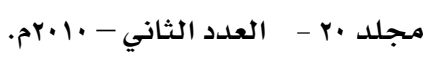

r- أمل بسيوني عطيه عابدين , سالى فوزى محمد الوراقى: " دراسة تأثير التنظيف الجاف على خواص الأداء

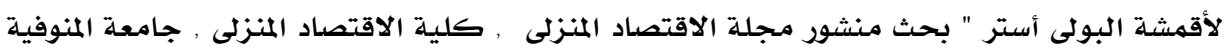

$$
\text { . } 9 \text {. } 9 \text {. }
$$

ع- أميرة عبدالله نور الدين: " تصميم مفروشات بالزخارف النباتية من بقايا الأقمشة وإمكانية استفادة الأسر

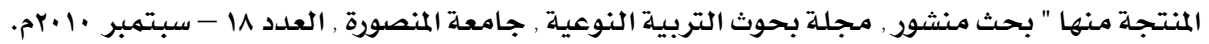
0- بسمة بهاء الدين كمال سعد: " مشاكل التصميم والتطريز فٍِ مجال المفروشات وكيفية التغلب عليها " ,رسالة دكتوراه , كلية الاقتصداد المنزلي , جامعة حلوان , عا+ب م.

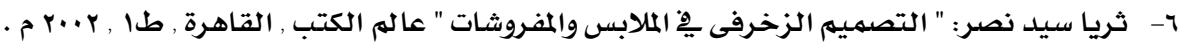


V- حسن عوض حسن الجندي: الإحصاء والحاسب الآلي :تطبيقاتIBM SPSS Statistics V21 مكتبة

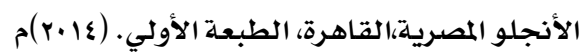

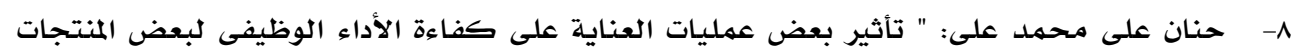

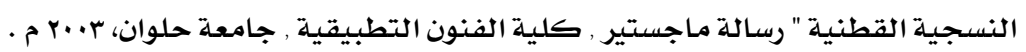

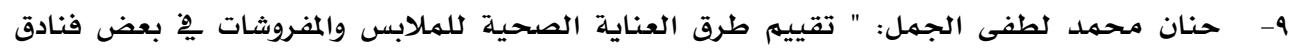

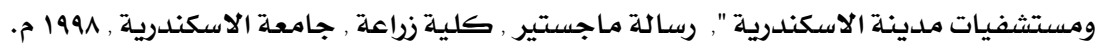

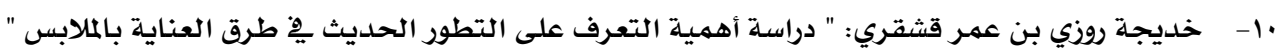

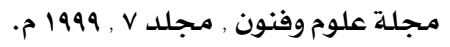

11- داليا أحمد محمد شكل: "استخدام الشرائط بِّ التطريز والتوصيل الزخربِ لاثراء المفروشات " رسالة

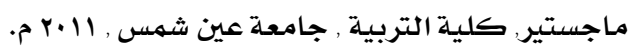
rا- رشا عباس محمد متولى الجوهري: " استخدام بعض أساليب التطريز وعلاقتها بالملائمة الوظيفية

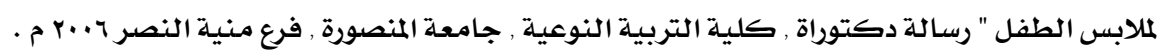

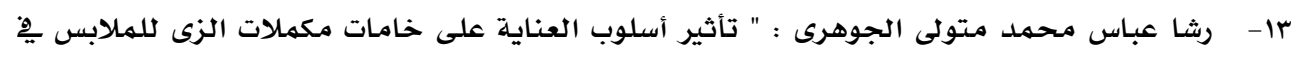

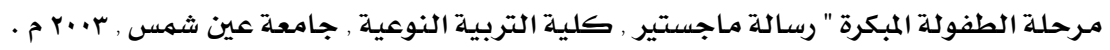

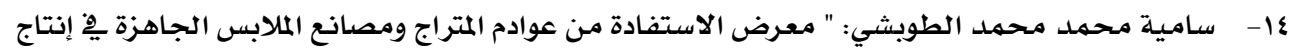

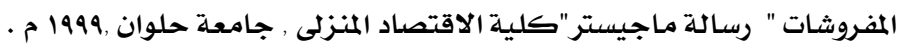

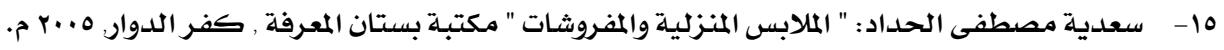

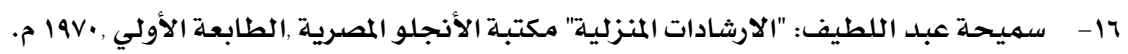

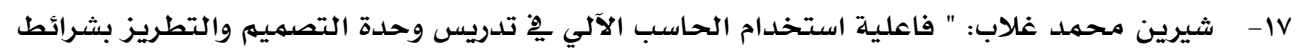

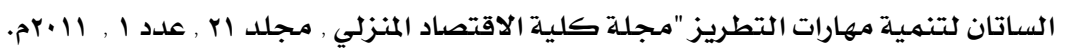

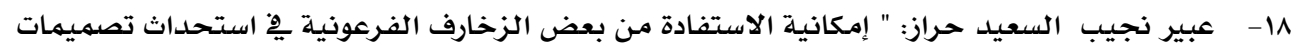

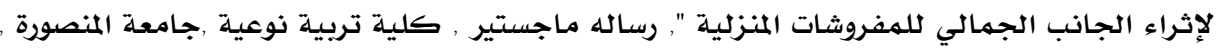
-

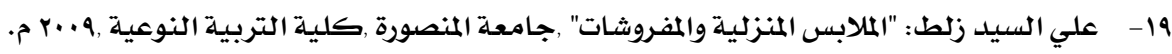

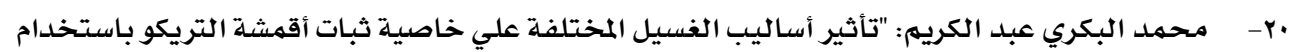

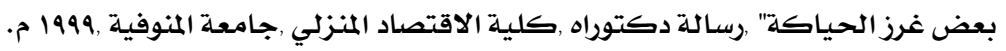

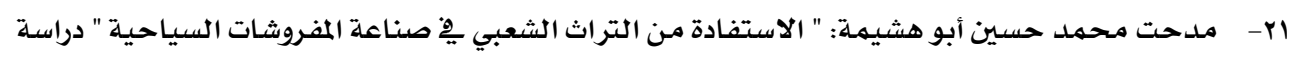

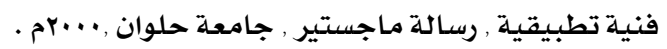

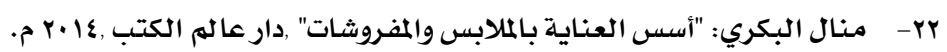

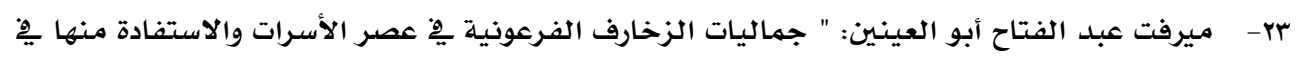

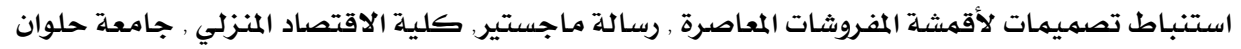
م 199. ع ع- وفاء فؤاد شلبي: "العناية بالملابس وأنسجة المفروشات المنزلية "مكتبة عين شمس , القاهرة ,1990 م . 


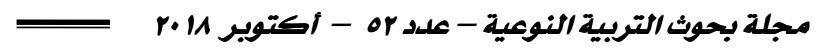

25. http://akhawat.imanhearts.com

26. http://akhawat.imanhearts.com/showthread.php

27. http://ar.aliexpress.com

28. http://arabic.alibaba.com

29. http://articulo.mercadolibre.com

30. http://crochet-amany.blogspot.com

31. http://donum.pro

32. http://egypt.souq.com

33. http://forum.hawahome.com

34. http://forums.betel3z.com/t24229-2

35. http://ghazlelbanat.com

36. http://moonyali.wordpress.com

37. http://uae.souq.com

38. http://vb.3dlat.com- 38

39. http://www.djelfa.info/vb/showthread.php? $\mathrm{t}=2016653$

40. http://www.fatakat.com

41. http://www.fatakat.com/thread/3372064

42. http://www.lakii.com

43. http://www.q8yat.com/t259133.html

44. http://www.suminmar.es

45. http://www.takhfeed.com

46. http://www.ward2u.com

47. http://www.bntmofeid.com/vb/showthread.php?t=2878

48. https://i2.wp.com/www.mmlakaty.com/wp-content/uploads

49. http://yaoota.com/magazine

50. https://dzh.univanet.com/page/834

51. https://www.hawaaworld.com

52. https://crafty4all.com 
Studying the effect of CARE method on embroidered beddings (towels) with Embroidery Style by Satin Stripes

\section{Abstract}

The aim of the research is to evaluate the embroidered beddings (towels) with embroidering by the satin strips before and after performing CARE method with determining the convenient care method. In addition, we aim to evaluate the functional and aesthetic aspects of embroidered beddings (towels) by satin strips before and after performing the CARE method. Thirty of towels are designed, and evaluation form involving three aspects (the functional, aesthetic and quality performance) is prepared. The designed beddings (towels) are evaluated in the light of evaluation form by 11 specialized juries.

\section{The most important results were as follows:}

There is a statistically significant difference at $(\leq 0.05)$ between the mean score of juries' evaluation (as a whole) and at each aspect of the juries' evaluation of embroidered beddings (towels) with Embroidery Style by Satin Stripes pre \& post Automatic and Hand washing in favor of Hand and Automatic pre washing.

There isn't a statistically significant difference at the level of $(\leq$ 0.05 ) between the mean score of juries' evaluation (as a whole) and at each aspect of the juries' evaluation of embroidered beddings (towels) with Embroidery Style by Satin Stripes after Hand and Automatic washing. 